\title{
The Logic of Collective Action Revisited
}

JOACHIM WEIMANN JEANNETTE BROSIG-KOCH TIMO HEINRICH

HEIKE HENNIG-SCHMIDT CLAUDIA KESER 


\title{
2018s-02
}

\section{The Logic of Collective Action Revisited \\ Joachim Weimann, Jeannette Brosig-Koch, Timo Heinrich, Heike Hennig-Schmidt, Claudia Keser}

Série Scientifique
Scientific Series

\author{
Montréal \\ Mars/March 2018
}

(C) 2018 Joachim Weimann, Jeannette Brosig-Koch, Timo Heinrich, Heike Hennig-Schmidt, Claudia Keser. Tous droits réservés. All rights reserved. Reproduction partielle permise avec citation du document source, incluant la notice (C). Short sections may be quoted without explicit permission, if full credit, including (C) notice, is given to the source.
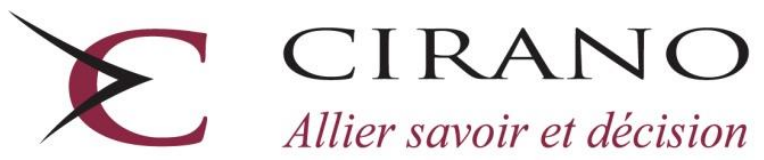

Allier savoir et décision

Centre interuniversitaire de recherche en analyse des organisations 


\section{CIRANO}

Le CIRANO est un organisme sans but lucratif constitué en vertu de la Loi des compagnies du Québec. Le financement de son infrastructure et de ses activités de recherche provient des cotisations de ses organisations-membres, d'une subvention d'infrastructure du gouvernement du Québec, de même que des subventions et mandats obtenus par ses équipes de recherche.

CIRANO is a private non-profit organization incorporated under the Quebec Companies Act. Its infrastructure and research activities are funded through fees paid by member organizations, an infrastructure grant from the government of Quebec, and grants and research mandates obtained by its research teams.

\section{Les partenaires du CIRANO}

\section{Partenaires corporatifs}

Autorité des marchés financiers

Banque de développement du Canada

Banque du Canada

Banque Laurentienne

Banque Nationale du Canada

Bell Canada

BMO Groupe financier

Caisse de dépôt et placement du Québec

Énergir

Hydro-Québec

Innovation, Sciences et Développement économique Canada

Intact Assurance

Investissements PSP

Ministère de l'Économie, de la Science et de l'Innovation

Ministère des Finances du Québec

Mouvement Desjardins

Power Corporation du Canada

Rio Tinto

Ville de Montréal

\section{Partenaires universitaires}

École de technologie supérieure

HEC Montréal

Institut national de la recherche scientifique

Polytechnique Montréal

Université Concordia

Université de Montréal

Université de Sherbrooke

Université du Québec

Université du Québec à Montréal

Université Laval

Université McGill

Le CIRANO collabore avec de nombreux centres et chaires de recherche universitaires dont on peut consulter la liste sur son site web.

Les cahiers de la série scientifique (CS) visent à rendre accessibles des résultats de recherche effectuée au CIRANO afin de susciter échanges et commentaires. Ces cahiers sont écrits dans le style des publications scientifiques. Les idées et les opinions émises sont sous l'unique responsabilité des auteurs et ne représentent pas nécessairement les positions du CIRANO ou de ses partenaires.

This paper presents research carried out at CIRANO and aims at encouraging discussion and comment. The observations and viewpoints expressed are the sole responsibility of the authors. They do not necessarily represent positions of CIRANO or its partners. 


\title{
The Logic of Collective Action Revisited
}

\author{
Joachim Weimann *, Jeannette Brosig-Koch', Timo Heinrich, \\ Heike Hennig-Schmidt ${ }^{\S}$, Claudia Keser ${ }^{* *}$
}

\begin{abstract}
Résumé/Abstract
Since Mancur Olson's „Logic of collective action” it is common conviction in social sciences that in large groups the prospects of a successful organization of collective actions are rather bad. Following Olson's logic, the impact of an individual's costly contribution becomes smaller if the group gets larger and, consequently, the incentive to cooperate decreases with group size. Conducting a series of laboratory experiments with large groups of up to 100 subjects, we demonstrate that Olson's logic does not generally account for observed behavior. Large groups in which the impact of an individual contribution is almost negligible are still able to provide a public good in the same way as small groups in which the impact of an individual contribution is much higher. Nevertheless, we find that small variations of the MPCR in large groups have a strong effect on contributions. We develop a hypothesis concerning the interplay of MPCR and group size, which is based on the assumption that the salience of the advantages of mutual cooperation plays a decisive role. This hypothesis is successfully tested in a second series of experiments. Our result raises hopes that the chance to organize collective action of large groups is much higher than expected so far.
\end{abstract}

\footnotetext{
${ }^{*}$ University of Magdeburg, Postbox 4120, 39016 Magdeburg, Germany; phone: +49-(0)391-6718547, email: weimann@ww.uni-magdeburg.de (corresponding author).

${ }^{\dagger}$ University of Duisburg-Essen, Universitätsstrasse 12, 45117 Essen, Germany; phone: +49-(0)201-1832479, email: jeannette.brosig@uni-due.de.

¥Durham University Business School, Millhill Ln, Durham DH1 3LB, UK; phone: +44-(0)191 334 5532, email: timo.heinrich@uni-due.de.

$\S$ University of Bonn, Adenauerallee 24-42, 53113 Bonn, Germany; phone: +49-(0)228-739195, email: hschmidt@uni-bonn.de.

${ }^{* *}$ University of Göttingen, Platz der Göttinger Sieben 3, 37073 Göttingen, Germany; phone: +49-(0)551-398040, email: claudia.keser@uni-goettingen.de.
} 


\section{Introduction: Olsons' argument and the cooperation problem}

As long ago as 1965 Mancur Olson (1965) put forward a theory that today still preoccupies the social sciences: large (latent) groups have great difficulty in providing collective goods. Olson argues "because of the small benefit each member of a large group receives, there is little likelihood that any one member (or a few members) will pay the cost of providing even some of the good' ( $p$. 48). As a consequence, large groups are hardly able to provide public goods or to organize their collective interests, in contrast to small groups, which are able to do so. This logic of collective action has far reaching implications. It suggests, among other things, that the problem of climate change will be exceedingly difficult to solve, if not insurmountable, as finding a solution to this challenge requires cooperative behavior within extremely large groups. If Olson's logic of collective action holds, significant contributions are not very likely.

The cooperation problem is frequently modeled with the help of the so-called voluntary contribution mechanism (VCM), introduced by Isaac et al. (1984). It allows Olson's argument to be expressed more precisely. Let $z_{i}$ denote the initial endowment of group member $i, b_{i}$ the individual contribution to the provision of the public good and $\alpha$ the return every group member receives if one monetary unit is invested in the production of the public good. The marginal return on the share of $z_{i}$ that is not invested in the public good is normalized to 1 . Then $\alpha$ is identical to the marginal per capita return $(M P C R)$ of investments in the public good. If $N$ is the number of group members, group member $i$ 's payoff $\pi_{i}$ is

$$
\pi_{i}=\left(z_{i}-b_{i}\right)+\alpha \sum_{j=1}^{N} b_{j} .
$$

A cooperation problem arises if the following holds:

$$
\alpha<1 ; N \alpha>1 \text { and thus } \alpha>1 / N .
$$

An individual investing one monetary unit in the public good receives a return of $\alpha$. Since $\alpha<1$, not investing is, from the individual's point of view, more profitable because the return of a monetary unit he keeps is equal to 1 . However, since $\alpha>1 / N$, from the group perspective it would still be efficient to invest. Individually rational behavior leads group members to keep their initial endowments $z_{i}$ and thus results in a return of $z_{i}$ to each group member. Cooperative behavior leads group members to invest all of their initial endowment and thus results in a return of $N \alpha z_{i}>z_{i}$. 
Clearly, the cooperation problem becomes more and more severe as $\alpha$ decreases, since the individual loss arising from contributing to the public good $(1-\alpha)$ increases.

Due to [1*] the $\operatorname{MPCR}(\alpha)$ is bounded by $1 / N$. In small groups, the value of the $M P C R$, therefore, has to be relatively high for a cooperation problem to arise, while this does not hold for large groups. Olson's argument boils down to the fact that the $M P C R$ can become very small in large groups. A very small absolute value of $\alpha$ means that the impact of an individual contribution on group members' individual payoffs becomes very small and therefore hardly noticeable, but the individual cost of a contribution does not change. It is not simply group size, but the barely perceptible $M P C R$ typically associated with large groups (and thus the interaction between $N$ and $M P C R$ ) that creates the difficulty of public good provision in these groups.

There is a very large body of literature dealing with public good experiments. ${ }^{1}$ Nearly all of these experiments are conducted with small groups of four to ten subjects using the VCM. The MPCRs used in these experiments range from 0.2 to 0.75 . However, the argument developed by Mancur Olson is only applicable in cases in which large groups try to produce a public good with a very small MPCR close to zero. Accordingly, experiments with small groups, in which the lower bound of $\alpha$ needs to be much higher than in large groups due to [1*], may not provide an appropriate test for Olson's argument.

To provide more appropriate evidence on the Olson hypothesis, we conducted experiments including larger groups of $N=100$ and 60 and very low MPCRs of 0.02 and 0.04 , among others. To test Olson's logic of collective action, we particularly focus on what we call the Olson hypothesis:

"Large groups with a very small MPCR close to zero are unlikely to provide the public good."

The MPCRs we use in our experiments are much smaller than those that have so far been studied with large groups; see Isaac et al. (1994) and Diederich et al. (2016), who also use groups of $N \geq$ 60 , but with much higher MPCRs of 0.30 or 0.75 , respectively. ${ }^{2}$ However, Isaac et al. (1994) also implemented one treatment in which seven groups of forty people faced an MPCR of 0.03. Six of these groups participated in a multiple-session design and were incentivized by extra credits while one group participated in a single-session design and was paid out in cash. The evidence provided

\footnotetext{
${ }^{1}$ For an early overview see Ledyard (1995) and for a more recent selective survey see Chaudhuri (2011).

${ }^{2}$ Schumacher et al. (2017) also use large groups but investigate a different research question.
} 
by Isaac et al. (1994) for this treatment is generally in line with cooperation patterns observed in small groups: average first-round contributions are larger than zero and average contributions fall with repetition ${ }^{3}$. However, compared to treatments with equal group size, but much higher MPCRs ( 0.30 or 0.75$)$, they find a lower initial average contribution and a much faster decay of average contributions, which seems to be in line with Olson's hypothesis. Our research suggests that this observation is driven by the particular combination of group size and $M P C R$ and that considerable contributions can be observed even when much larger groups $(N=100)$ are faced with a small $\operatorname{MPCR}(0.02$ or 0.04$)$.

We also observe in our large groups that a very small variation of the MPCR had a strong effect on contributions. To understand this effect, it is necessary to understand the interplay between group size and the MPCR. We develop a hypothesis concerning this interplay. The basic idea of our explanation is that the salience of the fact that cooperation is mutually advantageous may play a role for contributions. The more salient it is that the group benefits from cooperation, the more willing group members are to cooperate. As a proxy for the salience, we use the "MPCR distance", which is defined as the difference between the minimal MPCR $(1 / N)$ and the actual MPCR used in the experiment. We test our hypothesis in a second series of experiments, in which we implement a more complex variation of group size and MPCR. It turns out that the MPCR distance explains observed behavior better than alternatives discussed in the literature so far. Furthermore, our explanation might provide a better understanding of real-world cooperation problems and their solutions.

To our knowledge, this study is the first experimental analysis of public good provision focusing on large groups with different small MPCRs. Our study also extends the research on large-group public good experiments conducted by Isaac at al. (1994) and Diederich et al. (2016) in a methodological way. To provide a comparison to previously run small-group laboratory single-session VCM experiments as closely as possible in procedure, subject pool, and incentives, our experiments are based on a connected-lab design. That is, we run all our treatments with different subjects under laboratory conditions using cash incentives and student subject pools. This differs from the design used by Isaac at al. (1994) and Diederich et al. (2016) in several ways. Most importantly,

\footnotetext{
${ }^{3}$ This particularly holds for the six groups of the multi-session treatment who were incentivized by extra credits. The group in the simultaneous cash-reward session deviated in that cooperation decreased to about $5 \%$ in round 5 and to $0 \%$ in the final 10 th round.
} 
all sessions in Diederich et al. (2016) and most sessions in Isaac et al. (1994) are based on a multisession design in which the experiment lasted over several days and in which the default of a subject's decision was set to zero-contribution when he or she did not participate in a round. ${ }^{4}$

Thus, the contribution of our paper is three-fold. First, we provide evidence on behavior in large groups facing a very low MPCR and, thus, test Olson's hypothesis. Second, by systematically varying $M P C R$ and group size we are able to identify the specific interplay of group size and $M P C R$ that seems to drive the extent of cooperation. Third, we provide a methodological contribution as we use a new design that allows experiments with large groups to be run under controlled laboratory conditions, which is very similar to that employed when investigating small groups. Our paper proceeds as follows. Section 2 introduces the design and the results of our experimental sessions run to test the Olson hypothesis. Section 3 includes our conjecture on the specific interplay of $M P C R$ and group size, which is based on the findings reported in section 2. Section 4 presents the design and the results of our experimental sessions run to test this conjecture. Section 5 concludes.

\section{Experimental test of Olson's hypothesis}

\subsection{Design and procedure}

Running our large-group laboratory experiments required a laboratory where 100 subjects could interact simultaneously. Given the limited capacity of seats in experimental laboratories, we set up a sufficiently large virtual lab by connecting four different laboratories in Germany via the Internet. In all treatments - except for one small-group condition - we employed the connected-lab design: in this design, all groups consisted of subjects located at the laboratories of the Universities of Bonn, Duisburg-Essen, Göttingen, and Magdeburg (see Figure 1) who simultaneously decided on their individual contributions to the public good. The laboratory in Magdeburg coordinated all the sessions. We used zTree (Fischbacher 2007) for obtaining subjects' decisions and Skype for communicating between the laboratories. When entering the respective laboratory, subjects could see a (soundless) video conference of the four laboratories on a computer screen. Thus, each subject

\footnotetext{
${ }^{4}$ Isaac at al. (1994, p. 5) state, "Unfortunately, the effective size of laboratory experiments has been limited by both the expense of subject payments and by the capacity constraints of existing laboratories". Therefore, for about $90 \%$ of their sessions they employ a multi-session design using extra-credit point incentives for volunteers from undergraduate microeconomic theory classes who sometimes took part in more than one session.
} 
had the opportunity to verify that all laboratories were indeed connected and subjects were interacting simultaneously in real time. Subjects were not informed about the locations of the other laboratories.

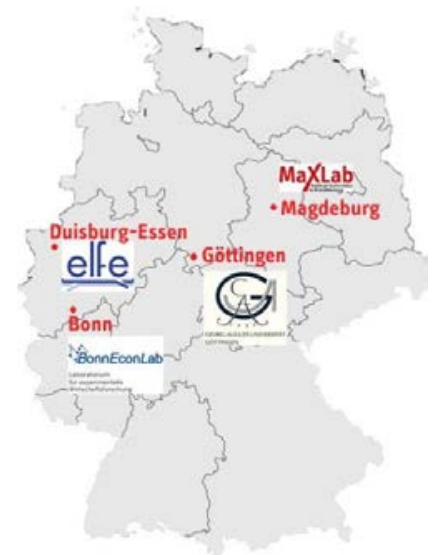

Figure 1. The four connected laboratories in Germany.

In all the treatments employed to test Olson's hypothesis, a standard linear ten-round public-good game with partner-matching was played. The payoff function corresponds to [1] in all treatments, with $z_{i}=120$ euro cents in each of the ten rounds. We collected data for eight groups in each treatment, i.e. we have eight independent observations per treatment.

\begin{tabular}{lcccccc}
\hline \hline Treatment & $N$ & MPCR & Sessions /indep. obs. & Lab & $\begin{array}{c}\text { Age } \\
\text { (years) }\end{array}$ & Female \\
\hline $8-0.25$ & 8 & 0.25 & 8 & connected & 23.297 & 0.547 \\
\hline $8-0.25-\mathrm{L}$ & 8 & 0.25 & $8 / 32$ & local & 22.773 & 0.590 \\
\hline $60-0.02$ & 60 & 0.02 & 8 & connected & 22.979 & 0.519 \\
\hline $60-0.04$ & 60 & 0.04 & 8 & connected & 23.125 & 0.517 \\
\hline $100-0.02$ & 100 & 0.02 & 8 & connected & 23.709 & 0.439 \\
\hline $100-0.04$ & 100 & 0.04 & 8 & connected & 23.169 & 0.487 \\
\hline
\end{tabular}

Table 1. Treatment parameters and participant characteristics.

Note: The table shows the parameters of the six treatments. In each treatment, we conducted eight sessions. Due to no-shows, in two sessions of 100-0.02 less than 100 subjects participated (98 and 99). In seven sessions of 100-0.04 we had less than 100 participants $(89,93,93,96,96,97$, and 99$)$. The table also summarizes the average age of participants and the share of female participants. 
We conducted treatments with groups consisting of 8, 60, and 100 members $^{5}$ (see Table 1). Recall that due to [ $\left.1^{*}\right]$, the $M P C R$ is bounded by $1 / N$, i.e. we cannot run all small- and large-group sessions with the same small MPCR. For $N=8$, we conducted two treatments with $M P C R=0.25$ to test if the connected-lab design has an impact on behavior. As in all connected-design treatments, in 80.25 , the members of each group were equally distributed over the four labs (i.e., in this treatment there were two subjects in each lab) whereas in the control treatment without a connected-lab design, 8-0.25-L, the eight subjects played locally in each of the labs.

At the beginning of each experimental session, subjects received written instructions ${ }^{6}$. Before the start of the first round of the public-good game, participants had to answer several questions concerning the payoff rules of the game in order to ensure that they had understood the game correctly. In all treatments, subjects were informed after each round about the amount they had kept, their own contribution, average contribution to the public good of all group members ${ }^{7}$, their individual payoff from the public good, their individual earnings in the round just completed, and the cumulated earnings over all previous rounds. They knew that they would be re-matched with the same people in each round and that the experiment would be finished after ten rounds. After round 10, subjects were paid their earnings over all 10 rounds in cash and left.

The sessions lasted for about 90 minutes and the average earning was 15.23 euros. Subjects were recruited via ORSEE (Greiner, 2015). A total of 2,840 different subjects participated in the six treatments and each subject participated in one session only. All sessions were run according to the same protocol.

\footnotetext{
${ }^{5}$ Because of no-shows, less than 100 subjects per group participated in two sessions of 100-0.02 and in seven sessions of 100-0.04, the average numbers being 99.625 and 95.375, respectively. All parameters based on group size were adapted in the respective sessions and subjects were informed about the correct number of participants. We also adjusted our data analyses accordingly. Since each individual decision in the first round is an independent observation, we can check if groups of less than (but close to) 100 behaved differently from those with exactly 100 subjects. We find no significant difference ( $p=0.136, n=797$ for $100-0.02$ and $p=0.390, n=763$ for 100-0.04, two-sided MannWhitney $U$ tests).

${ }^{6}$ See Appendix A for instructions of treatment 100-0.2, as an example.

${ }^{7}$ Subjects knew that they would only receive aggregate information about the behavior of other group members and therefore were not able to identify others' individual behavior.
} 


\subsection{Results}

\subsubsection{Impact of connected-lab design}

Before testing the Olson hypothesis, we studied, by means of two small-group treatments, whether the connected-lab design has an impact on subjects' behavior. First, we find the behavior in treatments $8-0.25$ and $8-0.25$-L follows the same pattern of contribution decline that is typically found in ten-round public-good experiments with small groups of $N \leq 10$ and $M P C R s \geq 0.30$ (cf. Footnote 1): on average, contributions start somewhere between $30 \%$ and $50 \%$ of the endowment and then decrease from round to round. In our treatments, average first-round contributions are $41.8 \%$ and $39.1 \%$ in $8-0.25$ and $8-0.25-\mathrm{L}$, and decrease to $12.6 \%$ and $14.6 \%$, respectively, with overall average cooperation rates of $26.9 \%$ and $26.1 \%$ (cf. Figure 2 and Table 2). Second, we cannot reject the hypothesis that average contributions are unaffected by the treatment variation. We find no significant difference between local groups and groups in the large virtual lab, neither regarding average contributions over all ten rounds nor concerning average contributions in each of the rounds ${ }^{8}$. From a methodological point of view, this finding is good news because it appears that the capacity of laboratories can be multiplied by connecting them virtually without inducing significant behavioral effects.

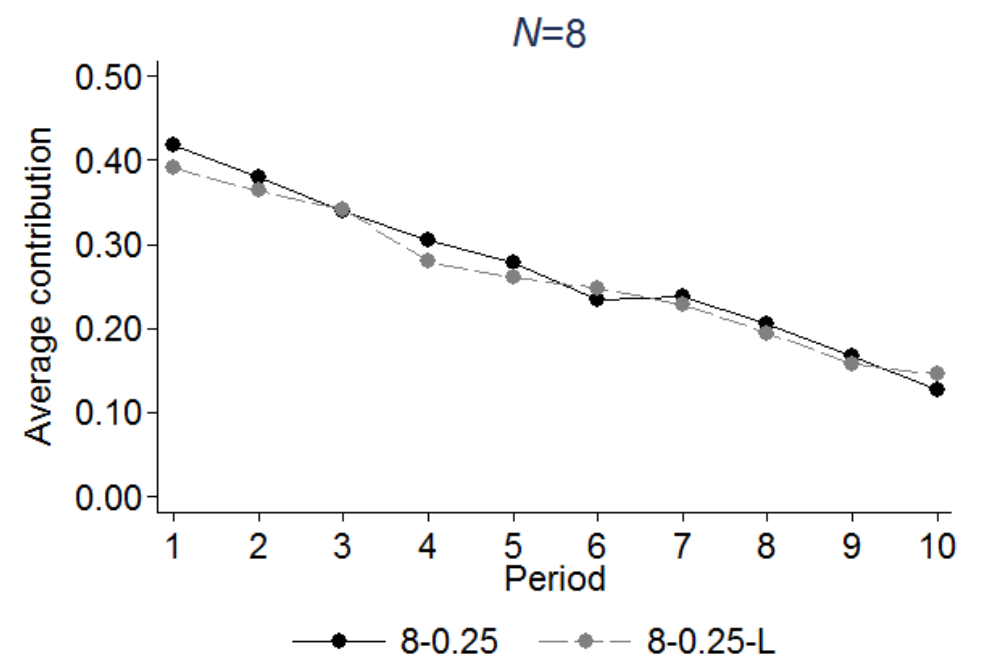

Figure 2. Average share of contributions in treatments 8-0.25 and 8-0.25-L.

Note: The graph shows the average contributions in each round as share of the endowment.

\footnotetext{
${ }^{8} p>0.264$ for comparing contributions in each of the 10 rounds and $p=0.685$ for comparing overall contributions (two-sided Mann-Whitney $U$ tests).
} 


\subsubsection{Testing the Olson hypothesis}

The Olson hypothesis says that large groups with a small MPCR close to zero are unlikely to provide the public good. In contrast, small groups with a much higher $M P C R$ will be able to provide a considerable amount of it. This would mean in our experiment that average cooperation rates of large groups should not be significantly different from zero and should be significantly smaller than those observed for small groups. We tested this hypothesis by using large groups of 60 and 100 subjects and very small MPCRs of 0.02 and 0.04 (Table 1). Treatment 8-0.25 served as the benchmark condition for cooperation in small groups with an MPCR that is 12.5 and 6.25 times as high as in the large-group treatments.

In all large groups, we find considerable positive average first-round contributions - between $26.3 \%$ and $39.1 \%$ (Table 2), which are significantly larger than zero; see the OLS-regressions in Table B1 of Appendix B, columns (9), (10), (12), and (13). Average contributions over all rounds are between $11.1 \%$ and $22.8 \%$. Moreover, we observe a pattern of contribution decline similar to that in our small groups. Average contributions in round 10 are between $2.8 \%$ and $7.7 \% .{ }^{9}$ In particular, the dynamics in 60-0.04 and 100-0.04 are rather similar to those in 8-0.25 (Figure 3 and Table B1). Average contributions in 100-0.04 do not differ significantly from those in 8-0.25 ( $p=$ $0.208, n=16$, two-sided Mann-Whitney $U$ test).

\begin{tabular}{lccc}
\hline \hline Treatment & \multicolumn{3}{c}{ Contributions } \\
\cline { 2 - 4 } & Round 1 & Round 10 & All rounds \\
\hline $8-0.25$ & 0.418 & 0.126 & 0.269 \\
& $(0.127)$ & $(0.101)$ & $(0.110)$ \\
\hline $8-0.25-\mathrm{L}$ & 0.391 & 0.146 & 0.261 \\
& $(0.13)$ & $(0.127)$ & $(0.146)$ \\
\hline $60-0.02$ & 0.263 & 0.028 & 0.111 \\
& $(0.047)$ & $(0.013)$ & $(0.021)$ \\
\hline $60-0.04$ & 0.356 & 0.075 & 0.202 \\
& $(0.028)$ & $(0.030)$ & $(0.019)$ \\
\hline $100-0.02$ & 0.321 & 0.037 & 0.134 \\
& $(0.047)$ & $(0.009)$ & $(0.021)$ \\
\hline $100-0.04$ & 0.391 & 0.077 & 0.228 \\
& $(0.053)$ & $(0.008)$ & $(0.031)$ \\
\hline \hline
\end{tabular}

${ }^{9}$ OLS-regressions reveal a quite similar decay across treatments of 3.1 percent of the endowment in $8-0.25$ and between 2.3 percent and 3.5 percent in the large groups. 
Table 2. Summary statistics.

Notes: The table shows the average contributions in rounds 1 and 10 as well as the average contribution over all rounds. Standard deviations in parentheses.

Our findings above clearly contradict Olson's theory that large groups with a small MPCR close to zero are unlikely to provide the public good in our experiment.

We next analyze the group-size effect, i.e. the impact on cooperation of increasing group size from $N=60$ to $N=100$, while holding the $M P C R$ constant. We also study the MPCR-effect, i.e. how increasing the MPCR from 0.02 to 0.04 affects cooperation at a given group size.

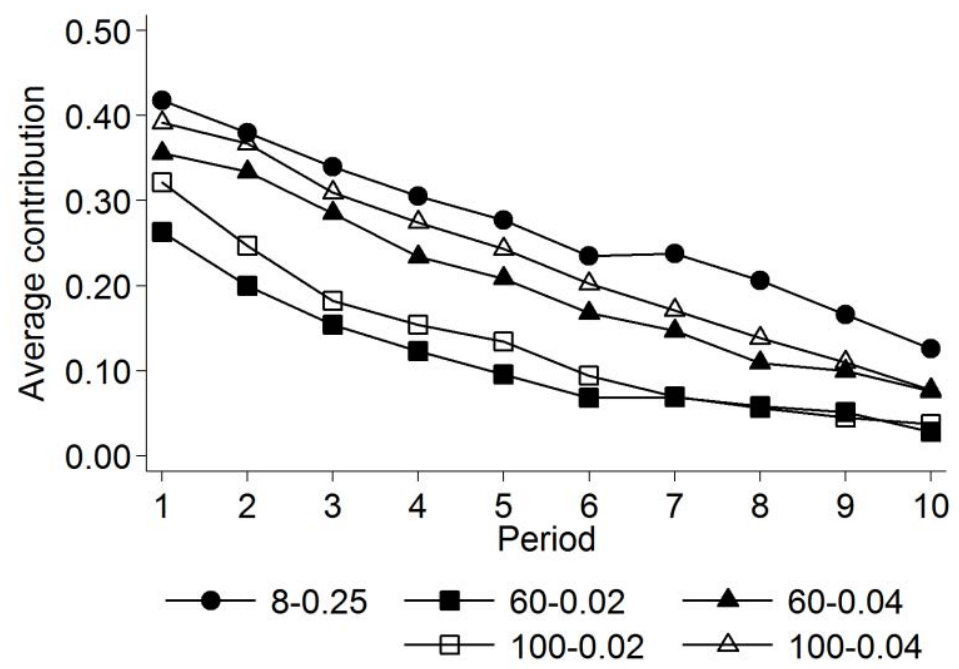

Figure 3: Average share of contributions per round in large groups with $N=60$ and 100 as well as in treatment 8-0.25.

Notes: The graph shows the average contribution in each round as share of the endowment for $N=60$ and 100 and different $M P C R$-values.

The group-size effect is positive, but moderate. Changing group size from 60 to 100 increases average contributions from $11.1 \%(20.2 \%)$ to $13.4 \%(22.8 \%)$ for an MPCR of 0.02 (0.04) (see Table 2). ${ }^{10}$ Columns (1) and (2) of Table B3 show OLS regression results, revealing that increasing group size pushes up contributions in round 1 significantly by 5.2 percent with an MPCR $=0.02$

\footnotetext{
${ }^{10}$ For a given $M P C R$, average contributions are (weakly) significantly lower in the 60- compared to the 100 -member groups $(p=0.046(0.093)$ for MPCR $=0.02(0.04)$, two-sided Mann-Whitney $U$ tests. Comparing contributions round by round yields (weakly) significant differences in seven rounds for an MPCR of 0.02 ( $p \leq 0.093$ ). For an MPCR of 0.04 only two rounds differ significantly by group size $(p \leq 0.093)$.
} 
and by 4 percent with an MPCR $=0.04$. In the latter case, contributions decay significantly faster, however.

The MPCR-effect is positive and strong. Increasing the MPCR slightly from 0.02 to 0.04 leads to a highly significant increase in average contributions from $13.4 \%(11.1 \%)$ to $22.8 \%(20.2 \%)$ in groups of 100 (60) (see Table 2). ${ }^{11}$ OLS-regressions in columns (3) and (4) of Table B3 show that raising the $M P C R$ increases contributions in round 1 by even 13.2 percent in groups of 60 and by 12 percent in groups of 100 . In both cases, the larger MPCR is associated with a faster decay of contributions.

While the positive $M P C R$ effect is in line with Olson's argument, the positive group-size effect seems to be counterintuitive in light of Olson's argument. Moreover, it is not clear why small groups confronted with a high $M P C R$ can achieve levels of cooperation similar to those of large groups confronted with very low MPCRs. The latter observation suggests that it is neither group size nor the value of $M P C R$ alone that determines the level of cooperation, but a specific interplay of both.

The conjecture that the interplay of group size and $M P C R$ is decisive for cooperation in public good experiments is also implied by previous research. Isaac and Walker (1988) observe that the impact of varying the $M P C R(0.3$ vs. 0.75$)$ depends on the size of the group: it is much stronger for $N=4$ than for $N=10$. While the authors refer to average contributions, the effects are already identifiable in the first rounds. Another interesting observation made by the authors is that for a high MPCR of 0.75 the group-size effect is rather weak (and not significant), but very strong for a low MPCR of 0.3 (p. 191). ${ }^{12}$ Isaac et al. (1984) make a similar observation, which is replicated in Isaac et al. (1994), who summarize their findings in stating that behavior in public good games "is influenced by a subtle interaction between group size and MPCR rather than simply the sheer magnitude of either" (p. 32). Gunnthorsdottir et al. (2007) find that for $N=4$ varying the MPCR $(0.3$, 0.5 , and 0.75 ) has a positive but non-linear impact on contributions. Increasing the MPCR from 0.3

\footnotetext{
${ }^{11}$ These differences are significant at the one-percent level when comparing group averages between treatments $(p=$ 0.001 , two-sided Mann-Whitney $U$ tests). Comparing contributions round by round yields significant differences by MPCR in all rounds ( $p \leq 0.036$ for $N=100$ and $p \leq 0.005$ for $N=60$ ).

${ }^{12}$ Efficiency concerns cannot explain this finding. For an MPCR of 0.3 , the group payoff resulting from investing $\$ 1$ each into the public good is $\$ 1.20$ in a group of four and $\$ 3.00$ in a group of ten. This increase in group size from four to ten significantly increases the contributions observed in the experiment. For an MPCR of 0.75 the group payoff resulting from a $\$ 1$-investment into the public good is $\$ 3$ in a group of four and $\$ 7.50$ in a group of ten. In this case, the increase in group size shows no significant impact on the average contribution.
} 
to 0.5 has a strong effect, while a further increase to 0.75 has a rather small effect. The differences between contributions already appear in the first round of the experiment. The authors argue that the increase in contributions can be explained by the fact that a higher MPCR makes it more effective to invest in the public good. ${ }^{13}$ However, this explanation cannot account for the decreasing strength of the MPCR-effect. Nosenzo et al. (2015) report that varying the size of small groups has a rather strong effect on first-round contributions for a low $M P C R$ of 0.3 , but no significant effect for a high $M P C R$ of $0.75^{14}$. Diederich et al. (2016) found a significant but weak group-size effect for an MPCR of 0.3 and groups of 10,40 , and 100 members.

\subsubsection{The interplay of MPCR and N: The MPCR-distance conjecture}

Based on our findings from testing Olson's hypothesis, we provide a conjecture on how the MPCR and the group size might interact with each other. This conjecture is different from approaches suggested by previous research. Consequently, we test it by running additional treatments that provide a more complex variation of group sizes and MPCRs (see section 3). Figure 4 spans the $N$ $M P C R$ space for representing the five connected-lab treatments conducted so far. The $1 / N$ curve reveals, for each group size, the minimal $M P C R$ necessary to create a social dilemma situation. ${ }^{15}$ For each treatment, the first number in the yellow label displays the average overall contributions in percent.

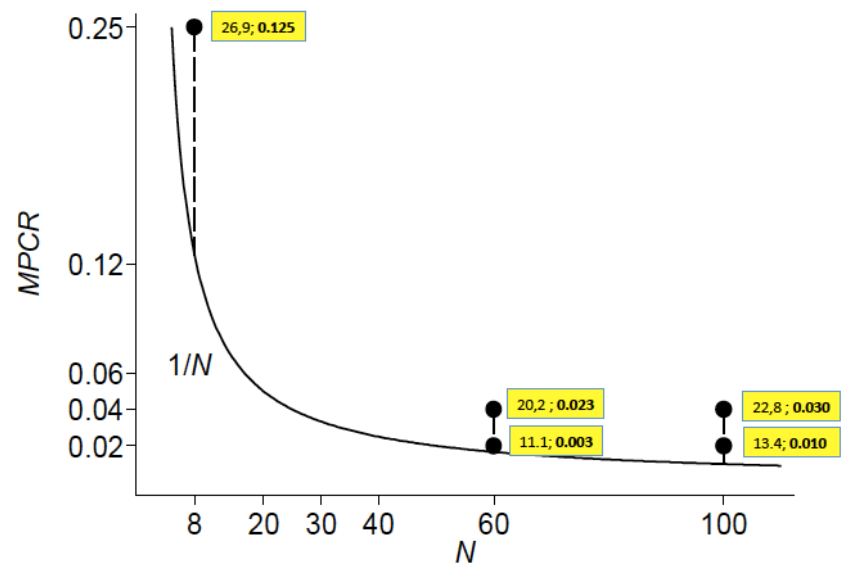

Yellow: first 5 treatments; $1^{\text {rst }}$ number: contribution; $2^{\text {nd }}$ number: MPCR-distance $d$

\footnotetext{
${ }^{13}$ In the sense that the total payment to all group members is higher per unit invested in the public good.

${ }^{14}$ In later rounds of their experiment, increasing group size turns out to even negatively affect contributions for $M P C R$ $=0.75$.

${ }^{15}$ As we have normalized the return of an investment in the private asset in equation [1] to $p=1$ in our experiment.
} 
Figure 4. $M P C R, N$, average contributions and $M P C R$-distances of the connected-lab treatments run so far.

Note: Each dot in the graph represents one $N-M P C R$ combination of the connected-lab treatments run so far. It also shows the $1 / N$-curve. The first numbers in the yellow labels are the percentages of average contributions for each treatment, the second numbers in bold are the respective MPCR-distances $d$.

Figure 4 reveals two remarkable observations concerning the vertical distance between the $M P C R$ and $1 / N$, which we will call the MPCR-distance $(d)$ in the following. First, reducing the MPCR at a given $N$ from 0.04 to 0.02 results in a decrease in average contributions - yet in a way that contributions are lowest when the MPCR-distance is minimal, i.e. at 60-0.02, where $d=0.003$ (see Figure 4 where the $d$ values are displayed by the second numbers in the yellow labels). Second, when this distance is comparatively large at $8-0.25(d=0.125)$, i.e. when reducing $N$ to 8 and increasing the $M P C R$ to 0.25 at the same time, average cooperation is not significantly different from that in 100-0.04 (Table B2). Thus, our results suggest that increasing $d$ has a positive but nonlinear impact on contributions, which is also in line with the findings from the literature reported in section 2.2.1.

The explanation is based on the observation that people confronted with a social dilemma can only be expected to cooperate if group members are aware that each person acting cooperatively is to everyone's advantage (e.g., Fischbacher and Gächter 2010). That means the mutual benefits of cooperation should be salient to the members of the group. Consequently, the more salient the advantage of cooperation is, the more subjects can be confident that group members have understood the social dilemma they are in and behave cooperatively.

We suggest the $M P C R$-distance $d$, i.e. $M P C R-1 / N$, be interpreted as a proxy for the salience of the fact that contributing to a public good is mutually beneficial. The $M P C R$ and $1 / N$ are parameters of the payoff function, which all subjects are informed about. As long as the $M P C R<1 / N$, investments in the public good are inefficient. If $1>M P C R>1 / N$, the overall efficiency gain from an investment in the public good increases (for a given $N$ ) in the MPCR. Thus, given our salience assumption, the higher $d$ is, the more salient the fact is that cooperation is mutually beneficial. It is not implausible to assume that the positive effect of salience on cooperation rates is not linear, but decreases with increasing salience. If subjects are considerably aware of the mutual benefits of cooperation (due to a higher salience), the additional impact of an increase in salience on cooperation rates might be lower than if subjects are not much aware of the benefits. Given the idea that 
cooperation depends (among others) on the salience of the cooperation advantage, which can be approximated by the $M P C R$-distance, the following conjecture can be formulated:

\section{MPCR-distance conjecture:}

1. Increasing the $M P C R$-distance $d$ has a positive effect on average contributions.

2. The higher the MPCR-distance $d$ already is, the less impact a further increase in $d$ has on average contributions.

We assume our conjecture also holds for first-round contributions as average cooperation is rather well predicted by first-round behavior (e.g., Keser and van Winden, 2000, Fischbacher and Gächter 2010, Engel et al. 2014). A test of our conjecture based on additional treatments that provide a more complex variation of the $M P C R$ and group size $N$ is reported in the next section. This test also includes alternative explanations mentioned in the literature so far. We investigate, in particular, the extent to which the different explanations (including our own conjecture) can account for observed behavior.

\section{Experimental test of the $M P C R$-distance conjecture}

\subsection{The interplay of $N$ and MPCR in the previous literature}

There are alternative explanations on the interplay between $N$ and the MPCR mentioned in the literature so far. Isaac et al. (1994) propose two approaches on how to explain the phenomena described in the previous sections. As a "starting point for characterizing the joint importance of group size and MPCR" (p. 23) in their VCM environment the authors suggest that cooperation depends on the maximal advantage an efficient solution has over the Nash outcome.

$$
\pi_{i}^{\text {Pareto }}-\pi_{i}^{\text {Nash }}=z_{i}[(N * M P C R)-1] .
$$

Since the endowment $z_{i}$ is given and fixed, (2) is an affine transformation of $N^{*} M P C R$ (i.e., the total payoff resulting from one monetary unit invested in the public good). Davis and Holt (1993) referring to Isaac et al. (1994), discuss $a=M P C R^{*} N$ as an explanatory variable for contributions. This is the first alternative hypothesis for the interplay of the MPCR and $N$ we will discuss. ${ }^{16}$

\footnotetext{
${ }^{16}$ The second explanation for contributions in a public good given by Isaac et al. (1994) is based on the idea that subjects could use their contributions as a signal that informs the other players about the own cooperative effort, hoping that this will motivate the other subjects to follow this example. We will not investigate this explanation in detail
} 
Davis and Holt (1993) also introduce the Minimal Profitable Coalition (MPC) as a second form of interaction between group size and the $M P C R$ that might be able to explain the contributions in public good experiments (also see Holt and Laury, 2008). The MPC is the minimal percentage of group members who must contribute to the public good such that contributing members have at least the same payoff compared to no one contributing. If the payoff from the private asset is normalized to 1 and $m M P C R=1$ then

$$
M P C=\frac{m}{N}
$$

Davis and Holt argue that cooperative behavior will be inversely related to the $M P C$. The higher the $M P C$, the more difficult it may be to build this coalition and the less promising it is to invest in the public good right from the start of the experiment. This highly plausible intuition cannot explain some of the above-mentioned results, however. For example, if for an MPCR of 0.75 the group size is increased from four to ten, this has been found to have only a small impact on contributions, although the $M P C$ falls from $50 \%$ to $20 \%{ }^{17}$ Davis and Holt at least implicitly assume that cooperation increases linearly with both the $M P C$ and the marginal social benefit $\left(N^{*} M P C R\right)$. This is an important point. If we compare the MPCR-distance $d$ with the MPC, we find that

$$
d=M P C R(1-M P C) .
$$

(4) implies that for a given $N, d$ and MPC would predict the same ordering of cooperation for different MPCRs if cooperation increases linearly with an increase in $d$ and with a decrease in MPC. (1-MPC) is the maximal share of non-cooperators that may exist in a group so that someone who cooperates earns at least as much as a non-cooperator. The main difference between our $M P C R$-distance conjecture and the MPC hypothesis is that in the case of the former it is a plausible assumption that the impact on contributions decreases in $d$ while the same assumption in the case of the MPC does not seem to be very plausible.

At this point, it should be noted that for the solution of real public good problems it could be very important whether the cooperation behavior depends on the salience of the cooperation advantages

because there is evidence that the signaling approach cannot explain cooperative behavior in public good experiments. For example, as we have shown in section 2, in a group of 100 it is nearly impossible to send a signal to the other players, although the cooperation patterns in those groups were the same as those in groups of 8 subjects.

${ }^{17}$ Both $a$ and $M P C$ usually suggest the same ordering of contributions across treatments. 
or on the size of the MPC. The salience of real cooperation benefits is likely to depend on other things than the size of MPCs.

\subsection{Experimental design and procedure}

The test of our conjecture and its comparison to alternative explanations is based on the standard linear ten-round public-good game with partners matching described in section 2.1. The experimental procedure employed for the eight new treatments is identical to that described in section 2.1. Over all 13 connected-lab treatments (including the five treatments from section 2), we changed the $M P C R$ from low $(0.02)$ over medium $(0.04,0.06)$ to higher values $(0.12,0.25)$. Likewise, we modified $N$ from high $(100,60)$ over medium $(30,40,20)$ to low $(8)$. Recall that due to [1*], the MPCR is bounded by $1 / N$, i.e. we could not conduct all treatments using the same (low) $M P C R$. Figure 5 displays our 13 treatments in the $N-M P C R$ space similar to Figure 5 . Table 3 provides summary statistics for the additional treatments.

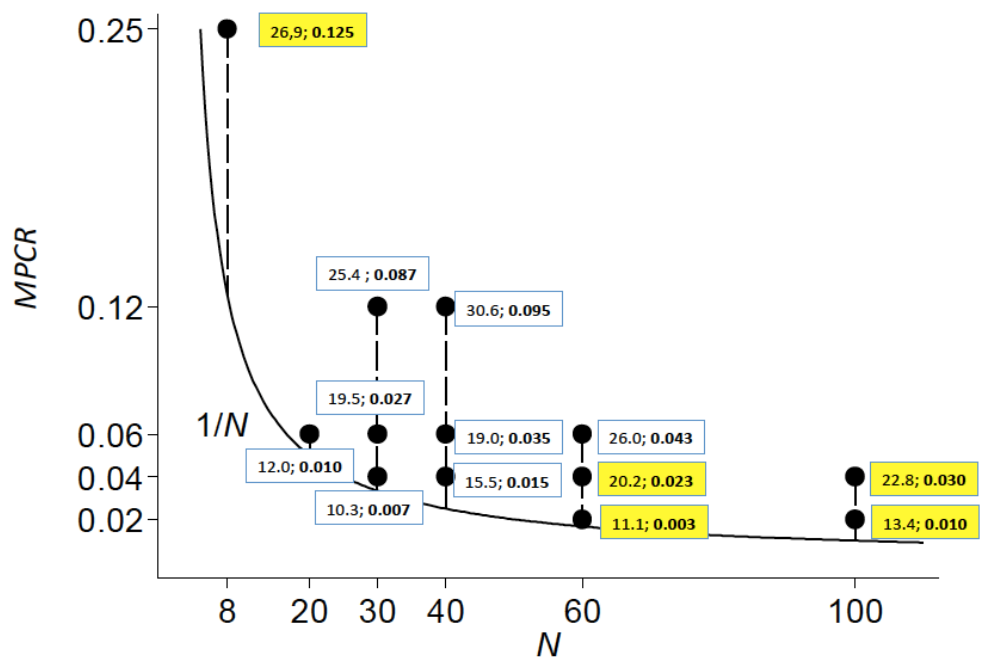

Figure 5. $M P C R, N$, average contributions, and $M P C R$-distances of all 13 connected-lab treatments.

Note: Each dot in the graph represents one $N-M P C R$ combination. It also shows the $1 / N$ curve. The first numbers in the labels are the percentages of average contributions for each treatment, the second numbers in bold are the respective $M P C R$-distances $d$. White labels mark additional treatments, yellow labels mark those analyzed in section 2 . 


\begin{tabular}{llccccc}
\hline \hline Treatment & $N$ & MPCR & Sessions /indep. obs. & Lab & $\begin{array}{c}\text { Age } \\
\text { (years) }\end{array}$ & Female \\
\hline $30-0.04$ & 30 & 0.04 & 8 & connected & 23.287 & 0.471 \\
\hline $30-0.06$ & 30 & 0.06 & 8 & connected & 22.729 & 0.525 \\
\hline $30-0.12$ & 30 & 0.12 & 8 & connected & 23.283 & 0.525 \\
\hline $40-0.04$ & 40 & 0.04 & 8 & connected & 22.734 & 0.531 \\
\hline $40-0.06$ & 40 & 0.06 & 8 & connected & 23.022 & 0.478 \\
\hline $40-0.12$ & 40 & 0.12 & 8 & connected & 22.784 & 0.569 \\
\hline $60-0.06$ & 60 & 0.06 & 8 & connected & 22.723 & 0.494 \\
\hline $20-0.06$ & 20 & 0.06 & 8 & connected & 22.581 & 0.500 \\
\hline
\end{tabular}

Table 3: Treatment parameters and participants' social characteristics in additional treatments.

Note: The table shows the parameters of the additional eight treatments to test the $M P C R$-distance conjecture. In each treatment, we conducted eight sessions with group size $N$ and the reported $M P C R$. The table also summarizes participants' average age and the share of female participants.

Overall, in this paper we conducted 14 treatments $^{18}$ and collected data for eight groups (independent observations) per treatment. In total, 5,160 different subjects participated in the experiments.

\subsection{Results}

Table 4 and Figure 5 present the average contribution rates in rounds 1 and 10 as well as over all the rounds and MPCR-distances for all 13 connected-lab treatments

18 The 13 connected lab treatments displayed in Figure 5 plus the local experiment with 8 subjects. 


\begin{tabular}{|c|c|c|c|c|}
\hline \multirow[t]{2}{*}{ Treatment } & \multicolumn{3}{|c|}{ Contributions } & \multirow{2}{*}{$\begin{array}{c}M P C R- \\
\text { distance } d\end{array}$} \\
\hline & Round 1 & Round 10 & All rounds & \\
\hline \multirow[t]{2}{*}{$8-0.25$} & 0.418 & 0.126 & 0.269 & 0.125 \\
\hline & $(0.127)$ & $(0.101)$ & $(0.110)$ & \\
\hline \multirow[t]{2}{*}{$20-0.06$} & 0.253 & 0.045 & 0.120 & 0.010 \\
\hline & (0.079) & $(0.035)$ & $(0.053)$ & \\
\hline \multirow[t]{2}{*}{$30-0.04$} & 0.264 & 0.040 & 0.103 & 0.007 \\
\hline & $(0.017)$ & $(0.032)$ & $(0.026)$ & \\
\hline \multirow[t]{2}{*}{$30-0.06$} & 0.404 & 0.049 & 0.195 & 0.027 \\
\hline & $(0.060)$ & $(0.020)$ & $(0.029)$ & \\
\hline \multirow[t]{2}{*}{$30-0.12$} & 0.374 & 0.148 & 0.256 & 0.087 \\
\hline & $(0.065)$ & $(0.028)$ & $(0.039)$ & \\
\hline \multirow[t]{2}{*}{$40-0.04$} & 0.348 & 0.052 & 0.155 & 0.015 \\
\hline & $(0.074)$ & $(0.034)$ & $(0.038)$ & \\
\hline \multirow[t]{2}{*}{$40-0.06$} & 0.356 & 0.071 & 0.190 & 0.035 \\
\hline & $(0.036)$ & $(0.029)$ & $(0.028)$ & \\
\hline \multirow[t]{2}{*}{$40-0.12$} & 0.419 & 0.183 & 0.306 & 0.095 \\
\hline & $(0.055)$ & $(0.06)$ & $(0.059)$ & \\
\hline \multirow[t]{2}{*}{ 60-0.02 } & 0.263 & 0.028 & 0.111 & 0.003 \\
\hline & $(0.047)$ & $(\mathbf{0 . 0 1 3})$ & $(0.021)$ & \\
\hline \multirow{2}{*}{ 60-0.04 } & 0.356 & 0.075 & 0.202 & 0.023 \\
\hline & $(0.028)$ & $(0.030)$ & $(0.019)$ & \\
\hline \multirow[t]{2}{*}{$60-0.06$} & 0.404 & 0.103 & 0.260 & 0.043 \\
\hline & $(0.054)$ & $(0.031)$ & $(0.046)$ & \\
\hline \multirow[t]{2}{*}{$100-0.02$} & 0.321 & $\mathbf{0 . 0 3 7}$ & 0.134 & 0.010 \\
\hline & $(0.047)$ & $(0.009)$ & $(0.021)$ & \\
\hline \multirow[t]{2}{*}{ 100-0.04 } & 0.391 & 0.077 & 0.228 & 0.030 \\
\hline & $(0.053)$ & $(0.008)$ & $(0.031)$ & \\
\hline
\end{tabular}

Table 4. Contributions and MPCR-distances in all connected-lab treatments.

Notes: The table shows the average contributions in rounds 1 and 10 as well as average contribution over all rounds. Standard deviations are given in parentheses. The MPCR-distance $d$ is shown as well. The bold treatments are those analyzed in section 2 . 
In all the additional treatments, we find considerable positive average first-round contributions between $25.3 \%$ and $40.19 \%$ (Table 3), which are significantly larger than zero; see the OLS-regressions in Table B1 of Appendix B, columns (3) to (8), (11), and (14). The overall average cooperation amounts to between $10.3 \%$ and $30.6 \%$. Moreover, we observe a similar pattern of contribution decline as in the treatments run before. Average contributions in round 10 are between 4.0\% and $18.3 \% .{ }^{19}$ Figures $\mathrm{C} 1$ in Appendix $\mathrm{C}$ illustrate the cooperation patterns observed in the new treatments.

To get a first impression whether the $M P C R$-distance is a decisive explanatory variable for contributions, we compare contributions in 100-0.02 and 20-0.06. Although $N$ and the MPCR differ by factor 5 and 3 respectively, the MPCR-distance is the same in both treatments. Therefore, our conjecture would predict very similar contributions in both treatments. Figure 6 demonstrates that this is indeed the case.

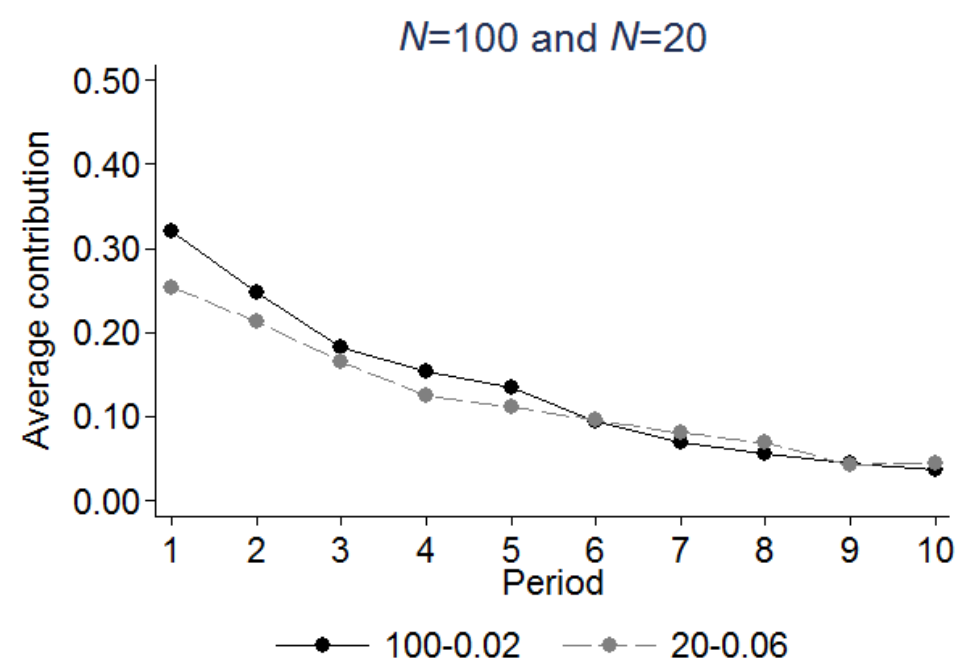

Figure 6: Average share of contributions per round in treatments with $M P R C$-distance $=0.10$

Notes: The graph shows the average contributions in each round as share of the endowment in treatments 100-0.02 and $20-0.06$ for $d=0.01$.

For the econometric analysis of our data we used the individual contributions as well as the group average to explain three dependent variables: first round contributions, average contributions, and last round contributions. These six regressions were run as OLS and as Tobit regressions, respectively. In sum, we have 12 different regressions. In each of these we used 15 different models and,

\footnotetext{
${ }^{19}$ OLS-regressions reveal a significant decay across treatments of between 2.1 percent and 3.7 percent (Table B1).
} 
as explanatory variables, $N$, the $M P C R$, the $M P C R$-distance $d, M P C$, and the efficiency measure $a$ $=M P C^{*} N$. All models were also run with a squared term of the explanatory variable and with a term accounting for the distance of the $M P C R$-distance from $1 / N$. We explain and discuss this term in the last section of this paper. In those regressions in which we used the individual data, we controlled (but do not report) for gender, the laboratory, and the age of the subjects. For individual regressions, the standard errors are clustered based on sessions; for group data we report the robust standard errors. To compare the different models directly we used the AIC (Akaike Information Criterion) and the BIC (Bayes Information Criterion). BIC differs from AIC insofar as it "punishes" additional parameters more strongly. It holds for both parameters that the model fit is better, the smaller the value of the information criterion is. As an important example, Table 5 reports the results for the Tobit regression of the average contributions using the group averages as independent variables. All regressions can be found in Appendix D. 


\begin{tabular}{|c|c|c|c|c|c|c|c|c|c|}
\hline & \multicolumn{3}{|c|}{$N$} & \multicolumn{3}{|c|}{$M P C R$} & \multicolumn{3}{|c|}{$d$} \\
\hline & $(1)$ & (2) & $(3)$ & $(4)$ & $(5)$ & (6) & $(7)$ & $(8)$ & $(9)$ \\
\hline$X$ & -0.000 & -0.000 & $-0.001 * * *$ & $0.692 * * *$ & $2.458 * * *$ & $0.432 * *$ & $1.467 * * *$ & $4.519 * * *$ & $1.016^{* * *}$ \\
\hline & $(0.000)$ & $(0.002)$ & $(0.000)$ & $(0.165)$ & $(0.331)$ & $(0.172)$ & $(0.220)$ & $(0.602)$ & $(0.265)$ \\
\hline$X^{2}$ & & $\begin{array}{c}0.000 \\
(0.000)\end{array}$ & & & $\begin{array}{l}-6.744 * * * \\
(1.522)\end{array}$ & & & $\begin{array}{c}-25.244 * * * \\
(5.883)\end{array}$ & \\
\hline$I^{d<1 / N}$ & & & $-0.143 * * *$ & & & $-0.100 * * *$ & & & $-0.087 * * *$ \\
\hline & & & $(0.027)$ & & & $(0.021)$ & & & $(0.015)$ \\
\hline$I^{d<1 / N} * X$ & & & $0.001 *$ & & & 0.589 & & & $3.019 * * *$ \\
\hline & & & $(0.000)$ & & & $(0.452)$ & & & $(0.579)$ \\
\hline Constant & $\begin{array}{l}0.208 * * * \\
(0.018)\end{array}$ & $\begin{array}{l}0.212^{* * *} \\
(0.040)\end{array}$ & $\begin{array}{l}0.286^{* * *} \\
(0.021)\end{array}$ & $\begin{array}{l}0.145^{* * *} \\
(0.011)\end{array}$ & $\begin{array}{l}0.077 * * * \\
(0.013)\end{array}$ & $\begin{array}{l}0.194 * * * \\
(0.014)\end{array}$ & $\begin{array}{l}0.137 * * * \\
(0.008)\end{array}$ & $\begin{array}{l}0.091 * * * \\
(0.009)\end{array}$ & $\begin{array}{l}0.175^{* * * *} \\
(0.013)\end{array}$ \\
\hline Obs. & 104 & 104 & 104 & 104 & 104 & 104 & 104 & 104 & 104 \\
\hline AIC & -231.917 & -229.945 & -289.419 & -265.802 & -284.811 & -294.280 & -301.756 & -332.282 & -318.690 \\
\hline $\mathrm{BIC}$ & -223.983 & -219.367 & -276.197 & -257.869 & -274.233 & -281.059 & -293.823 & -321.705 & -305.468 \\
\hline
\end{tabular}

\begin{tabular}{|c|c|c|c|c|c|c|}
\hline & \multicolumn{3}{|c|}{$M P C$} & \multicolumn{3}{|c|}{$a$} \\
\hline & (10) & $(11)$ & (12) & (13) & (14) & (15) \\
\hline$X$ & $\begin{array}{l}-0.003 * * * \\
(0.000)\end{array}$ & $\begin{array}{l}-0.004 * * \\
(0.002)\end{array}$ & $\begin{array}{l}-0.003 * * * \\
(0.001)\end{array}$ & $\begin{array}{l}0.049 * * * \\
(0.004)\end{array}$ & $\begin{array}{l}0.101^{* * *} \\
(0.024)\end{array}$ & $\begin{array}{l}0.035 * * * \\
(0.010)\end{array}$ \\
\hline$X^{2}$ & & $\begin{array}{c}0.000 \\
(0.000)\end{array}$ & & & $\begin{array}{l}-0.009 * * \\
(0.004)\end{array}$ & \\
\hline$I^{d<1 / N}$ & & & -0.023 & & & $-0.145^{* * *}$ \\
\hline$I^{d<1 / N} * X$ & & & $\begin{array}{c}(0.044) \\
0.000\end{array}$ & & & $\begin{array}{l}(0.045) \\
0.075^{* * *}\end{array}$ \\
\hline Constant & $\begin{array}{l}0.325^{* * *} \\
(0.012)\end{array}$ & $\begin{array}{l}0.353^{* * *} \\
(0.038)\end{array}$ & $\begin{array}{l}(0.001) \\
0.335^{* * *} \\
(0.031)\end{array}$ & $\begin{array}{l}0.076^{* * *} \\
(0.012)\end{array}$ & $\begin{array}{c}0.015 \\
(0.026)\end{array}$ & $\begin{array}{l}(0.023) \\
0.125^{* * *} \\
(0.034)\end{array}$ \\
\hline Obs. & 104 & 104 & 104 & 104 & 104 & 104 \\
\hline AIC & -308.026 & -306.763 & -304.320 & -302.338 & -304.173 & -307.886 \\
\hline $\mathrm{BIC}$ & -300.093 & -296.186 & -291.098 & -294.405 & -293.595 & -294.664 \\
\hline
\end{tabular}

Notes: Robust standard errors in parentheses, $* p<0.10,{ }^{* *} p<0.05,{ }^{* * *} p<0.01$

Table 5: Tobit regression of the average group contribution. 
Model (8) has the best fit of all the models used. In this model, the MPCR-distance $d$ and $d^{2}$ are the explanatory variables. Among the 12 regressions we report in Appendix D, model (8) is the one with the best fit in nine of the regressions. Model (9) performs slightly better in the Tobit regression of the first-round contributions if the group averages are used. In this model, the term $d^{2}$ is replaced by the term measuring the distance of the MPCR-distance from $1 / N^{20}\left(I^{d<1 / N}\right)$ and the interaction of this term with $d$.

Model (12) performs best for the OLS and the Tobit regression of the first-round contributions when individual data are used. Only the BIC value of model (10) is better in the OLS regression of first round contributions. Notwithstanding, when the first-round contributions are explained by individual data, models (8) and (9) show that the coefficients of $d$ and $d^{2}$ are highly significant and the differences of AIC and BIC to models (12) and (10) - which use the MPC as explanatory variable - are moderate.

In summary, the comprehensive econometric analysis shows that the MPCR-distance, in particular when combined with $d^{2}$, has a high explanatory power. Although our MPCR-distance hypothesis and the MPC model of Davis and Holt predict the same ordering of contributions ${ }^{21}$, the models using the MPCR-distance in most of the regressions outperform the model using MPC. We interpret this as strong evidence for our conjecture.

\section{Discussion}

Public-good problems in the real world very often are problems concerning large groups. The question of whether the ability to cooperate depends on the size of a group has been a topic of research at least since Mancur Olson's famous book about the logic of collective action. The experimental investigation of group size effects in public good games suffers from two fundamental problems. First, if the group size is varied, it is unavoidabe that other parameters characterizing the experimental situation also change; for example, increasing the size of the group ceteris paribus also increases the overall efficiency of a contribution. Furthermore, observations reported in the literature indicate that group-size effects might interact with the $M P C R$ defined by the payoff function utilized in an experiment. Second, from an operational point of view, it is rather difficult to conduct

\footnotetext{
20 This is equivalent to the distance of the $M P C R$ from $2 / N$

${ }^{21}$ At least in their linear versions.
} 
experiments with large groups - and it is expensive. Therefore, it has not systematically been analyzed whether the results of experiments with small groups and large values of the MPCR can be applied to large groups trying to provide public goods with very small values of the $M P C R$.

Our experiments with $N=60$ and 100 subjects and very low MPCRs of 0.02 and 0.04 clearly demonstrate two central results. First, the level of the contribution and the way contributions decay over the course of the experiment do not differ from those in small groups with $N=8$ and a relatively high MPCR of 0.25 . Therefore, we clearly have to reject Olson's hypothesis that cooperation will break down if the individual impact on group welfare (which can be measured by the MPCR) becomes very small.

Second, the positive $M P C R$-effect is rather strong, while the positive group-size effect is comparatively weak. These findings go along with the insight that an interaction between group size and $M P C R$ should exist, otherwise the similarity in contributions between groups of $N=8$ and an $M P C R=0.25$ and a group of $N=100$ and an MPCR of 0.04 cannot be explained. This interaction might be very important not only for understanding the behavior in public-good problems in the lab, but also in reality, and it therefore deserves closer inspection.

Large groups can only be expected to cooperate if it is clear to all members that each person acting cooperatively is to everyone's advantage. In laboratory experiments, the salience of the advantages of cooperation depends on the payoff function's parameters. We propose the difference between the actual MPCR and 1/N(the MPCR-distance $d$ ) as a proxy for this salience. We further conjecture that the effect of $d$ on cooperation is not linear, but decreases with $d$. If the MPCR-distance is high enough, the situation can be assumed as being perceived salient by the group members. Therefore, a further increase in salience would affect contributions only slightly - if at all.

In a series of experiments with group sizes varying from 8 to 100, we tested our conjecture and compared it with the MPC and the marginal social benefit hypotheses introduced by Douglas Davis and Charles Holt (1993) and Isaac et al. (1994). The regression analysis supports our explanation of the interaction between $N$ and the $M P C R$. Although the $M P C$ hypothesis also has its merits, our results show that our MPCR-distance and salience explanation performs better with respect to overall contribution levels and, moreover, is compatible with the observations made by Isaac et al. (1994) and Diederich et al. (2016). 
One open question is what is meant by the statement the MPCR-distance is 'high enough' such that a further increase in $d$ would not affect contributions any more. To answer this question, we rewrite the definition of $d$ as follows:

$$
d=\frac{N M P C R-1}{N}
$$

The numerator of this term is the net group benefit from a contribution to the public good. ${ }^{22}$ This net benefit has to be larger than 0 in order to create a public good problem.

One might argue that there exists some level of $d$ at which the information that cooperation is mutually advantageous is almost common knowledge among group members. In that case, a further increase in the salience may affect contributions only slightly. A natural prerequisite for this would be that the net benefit should be at least as high as the private benefit from not contributing to the public good. This implies that the net benefit should be at least 1 and therefore $d=1 / N$. This implies that the salience-critical MPCR is $2 / N$. Between the minimal MPCR $1 / N$ and the salience-critical $M P C R 2 / N$ the $(N, M P C R)$ combinations are such that a social dilemma exists, but it is not very salient, because the net group benefit of a contribution is smaller than the individual profit resulting from an investment in the private asset. Thus, variations of $d$ between $1 / N$ and $2 / N$ should have a rather strong impact on contributions while variations above $2 / N$ should have a less pronounced impact. Unfortunately, the design of our experiments does not allow this conjecture to be tested. To do this, additional experiments would be necessary.

However, even without the additional conjecture concerning the salience-critical MPCR-distance, our results have an important implication for the experimental investigation of public-good situations. They demonstrate that behavioral dynamics are the same in small groups with a high MPCR and in large groups with a small $M P C R$. Thus, small groups seem to be well suited to cover essential characteristics of public goods in a laboratory situation.

At the same time, our explanation of behavior in those experiments implies that the salience of the social dilemma seems to be of great importance for the investigation of real public-good problems. For example, in the case of environmental problems it would be important that, first, people know that their own cooperative contribution is efficiency enhancing and that, second, they are convinced

\footnotetext{
${ }^{22}$ One euro invested in the public asset results in a total payment to the group of $N M P C R$. The opportunity cost of this investment is 1 .
} 
that the social dilemma situation and the mutual benefit of contributions is common knowledge for all the people in the group. In societies fostering an intense debate on environmental protection, it is more salient to people that everyone would profit from mutual support of climate protection and for many (even if by no means for all) this seems to be a sufficient reason to act cooperatively and make a contribution. The salience of real-world public-good problems will probably not only depend on the MPCR-distance - not least because it is not known outside the lab. Identifying additional influences, therefore, is an important task for future research. 


\section{Literature}

Berg J., J. Dickhaut, K. McCabe, Berg, J., Dickhaut, J., McCabe, K. 1995. Trust, reciprocity and social history. Games and Economic Behavior, 10, 122-142.

Chaudhuri, A. 2011. Sustaining Cooperation in Laboratory Public Goods Experiments: A Selective Survey of the Literature. Experimental Economics, 14(1): 47-83.

Davis, D.D., Holt, C.A. 1993. Experimental Economics (Princeton Univ. Press, Princeton, N.Y.)

Engel, C., Beckenkamp, M., Glöckner, A., Hennig-Schmidt, H., Irlenbusch, B., Kube, S., Kurschilgen, M., Morell, A., Nicklisch, A., Normann, H.-T., Towfigh, E. 2014. First Impressions are More Important than Early Intervention: Qualifying Broken Windows Theory in the Lab, International Review of Law and Economics, 37, 126-136

Greiner B. 2015. Subject pool recruitment procedures: organizing experiments with ORSEE. Journal of the Economic Science Association, 1, 114-125. DOI 10.1007/s40881-015-0004-4.

Gunnthorsdottir, A., Houser, D., McCabe, K. 2007. Disposition, History and Contributions in Public Goods Experiments. Journal of Economic Behavior \& Organization, 62(2), 304-15.

Hardin G. 1968. The Tragedy of the Commons. Science, 162, 1243-1248.

Isaac, M., Walker, J., Thomas, S. 1984. Divergent evidence on free riding: An experimental examination of some possible explanations. Public Choice, 43, 113-149.

Isaac, R. M., Walker, J. M. 1988. Group Size Effects in Public Goods Provision: The Voluntary Contributions Mechanism. Quarterly Journal of Economics, 103(1): 179-99.

Isaac, R. M., Walker, J. M., Williams, A. W. 1994. Group Size and the Voluntary Provision of Public Goods. Experimental Evidence Utilizing Large Groups. Journal of Public Economics, 54(1): $1-36$.

Keser, C., van Winden, F. 2000. Conditional Cooperation and Voluntary Contributions to Public Goods. Scandinavian Journal of Economics, 102(1): 23-39.

Ledyard J. O. 1995. in Handbook of Experimental Economics, J.H. Kagel, A.E. Roth, Eds. (Princeton Univ. Press, Princeton, N.Y.), pp. 111-194. 
Olson, M. 1965. The Logic of Collective Action. Public Goods and the Theory of Groups (Harvard University Press, Cambridge, Mass., 5th printing 1975).

Sally, D. 1995. Conversation and Cooperation in Social Dilemmas. A Meta-analysis of Experiments from 1958 to 1992. Rationality and Society 7(1): 58-92.

Schumacher, H., Kesternich, I., Kosfeld, M., Winter, J. 2017. One, two, many-Insensitivity to group size in games with concentrated benefits and dispersed costs. The Review of Economic Studies, 84(3), 1346-1377. 


\section{Appendix A: Instructions}

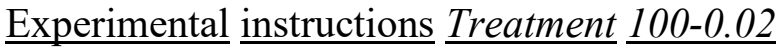

(Instructions for other treatments $\underline{\text { can }} \underline{\text { be provided }} \underline{\text { upon request) }}$

Preliminary: You are participating in an economic experiment focusing on decision making. If you have any questions after having read these instructions or during the experiment, please raise your hand. We will then come to your cubicle.

While participating in the experiment, you have to take a sequence of decisions. You will earn money. But, how much money you earn will depend both on your decision and the decisions of the other participants. Your total earnings will be paid in cash at the end of the experiment. Both your decisions and your payoff are confidential, i.e. no other participant will receive this information.

You are part of a group of 100 participants. These 100 people are located in four experimental laboratories across Germany, connected by Internet. All the group members have received the same instructions. Furthermore, the laboratories are linked with a video connection. If you have any doubts about this procedure, please take a look at our video conference.

You and the other 99 group members are facing the following identical decision situation during 10 consecutive rounds. In each round, you receive an endowment of 120 euro cents. You decide how much of this endowment you want to "keep", and how much you want to "contribute". Each contribution $x$ creates an amount of $0.02 x$ for each group member (including the contributor). That means that for every euro cent you contribute, the members of the whole group will be paid 2 euro cents $(0.02 \cdot x \cdot 100)$ each. For each euro cent you contribute, you will be paid 0.02 euro cents, like all other group members. That part of your endowment that you do not contribute (i. e. that you "keep"), you keep for yourself.

Summing up in one formula, your earnings in euro cents per round are as follows:

$$
120-\text { Your Contribution }+0.02 \cdot(\text { Sum of all group members' contributions) }
$$

Please note that your contribution per round can be any amount between 0 and 120 euro cents and that all group members are facing an identical decision situation. After each round you will be informed of the amount you kept, your contribution, the average contribution of all 100 group members, your payoff based on the contributions of all group members, your payoff in the respective round and your payoff cumulated over all rounds. In addition, you will see a table listing the same information for all previous rounds.

Practice rounds: Before starting the experiment, you have the opportunity to decide in three practice rounds. In these practice rounds, the average contribution of all other group members will be given since it is randomly generated. Furthermore, your own contribution will be preset, too. Your task is to calculate the earnings in the respective round yourself. To that end, we will provide you with a calculator, paper, and pencil. After entering your solution into the respective box, please click on the "Solution" button. You then will be informed whether your answer is right or wrong. The calculation method will also be shown. If you have any questions during the practice rounds, please raise your hand. Once the practice rounds are over, the experiment will immediately start automatically.

Payoff: Please stay in your cubicle after all 10 rounds have ended. You will be called individually to receive your payoff. Please hand in your participation number (which you drew at the 
beginning of the experiment) and enter your name and signature in the payment list. Please leave the laboratory after receiving your money.

Finally, we would like to ask you to not talk to anybody about the content of this experiment to avoid influencing future participants. Thank you for your cooperation! 


\section{Appendix B: Tables}

\begin{tabular}{|c|c|c|c|c|c|c|}
\hline & (1) & (2) & (3) & (4) & (5) & \\
\hline & $8-0.25$ & $8-0.25 \mathrm{~L}$ & $30-0.04$ & $30-0.06$ & $30-0.12$ & \\
\hline \multirow[t]{3}{*}{$t-1$} & $-0.031^{* * *}$ & $-0.028 * * *$ & $-0.021 * * *$ & $-0.037 * * *$ & $-0.026^{* * *}$ & \\
\hline & $(0.005)$ & $(0.001)$ & $(0.002)$ & $(0.002)$ & $(0.002)$ & \\
\hline & {$[0.000]$} & {$[0.000]$} & {$[0.002]$} & {$[0.000]$} & {$[0.002]$} & \\
\hline \multirow[t]{3}{*}{ Constant } & $0.406 * * *$ & $0.385 * * *$ & $0.197 * * *$ & $0.364 * * *$ & $0.371 * * *$ & \\
\hline & $(0.029)$ & $(0.005)$ & $(0.011)$ & $(0.013)$ & $(0.011)$ & \\
\hline & {$[0.000]$} & {$[0.000]$} & {$[0.011]$} & {$[0.000]$} & {$[0.011]$} & \\
\hline Observations & 80 & 320 & 80 & 80 & 80 & \\
\hline R-squared & 0.342 & 0.687 & 0.647 & 0.837 & 0.707 & \\
\hline $\mathrm{AIC}$ & -106.162 & -961.900 & -267.608 & -256.601 & -257.195 & \\
\hline \multirow[t]{3}{*}{ BIC } & -101.398 & -954.363 & -262.844 & -251.837 & -252.431 & \\
\hline & (6) & (7) & $(8)$ & (9) & (10) & (11) \\
\hline & $40-0.04$ & $40-0.06$ & $40-0.12$ & $60-0.02$ & $60-0.04$ & $60-0.06$ \\
\hline \multirow[t]{3}{*}{$t-1$} & $-0.031 * * *$ & $-0.030 * * *$ & $-0.026 * * *$ & $-0.023 * * *$ & $-0.032 * * *$ & $-0.034 * * *$ \\
\hline & $(0.002)$ & $(0.002)$ & $(0.002)$ & $(0.002)$ & $(0.001)$ & $(0.002)$ \\
\hline & {$[0.000]$} & [0.002] & [0.002] & {$[0.002]$} & [0.001] & [0.002] \\
\hline \multirow[t]{3}{*}{ Constant } & $0.293 * * *$ & $0.325 * * *$ & $0.424 * * *$ & $0.215 * * *$ & $0.347 * * *$ & $0.412 * * *$ \\
\hline & $(0.015)$ & $(0.009)$ & $(0.012)$ & $(0.010)$ & $(0.007)$ & $(0.011)$ \\
\hline & {$[0.000]$} & [0.009] & {$[0.012]$} & {$[0.010]$} & [0.007] & [0.011] \\
\hline Observations & 80 & 80 & 80 & 80 & 80 & 80 \\
\hline R-squared & 0.722 & 0.838 & 0.563 & 0.771 & 0.893 & 0.780 \\
\hline $\mathrm{AIC}$ & -233.852 & -292.775 & -203.222 & -299.712 & -318.466 & -244.120 \\
\hline \multirow[t]{3}{*}{$\mathrm{BIC}$} & -229.088 & -288.011 & -198.458 & -294.948 & -313.702 & -239.356 \\
\hline & (12) & (13) & (14) & & & \\
\hline & $100-0.02$ & $100-0.04$ & $20-0.06$ & & & \\
\hline \multirow[t]{3}{*}{$t-1$} & $-0.030 * * *$ & $-0.035 * * *$ & $-0.022 * * *$ & & & \\
\hline & $(0.002)$ & $(0.001)$ & $(0.002)$ & & & \\
\hline & {$[0.000]$} & {$[0.001]$} & {$[0.002]$} & & & \\
\hline \multirow[t]{3}{*}{ Constant } & $0.268 * * *$ & $0.387 * * *$ & $0.221 * * *$ & & & \\
\hline & $(0.011)$ & $(0.010)$ & $(0.016)$ & & & \\
\hline & {$[0.000]$} & {$[0.010]$} & {$[0.016]$} & & & \\
\hline Observations & 80 & 80 & 80 & & & \\
\hline R-squared & 0.832 & 0.882 & 0.527 & & & \\
\hline $\mathrm{AIC}$ & -290.521 & -295.959 & -216.542 & & & \\
\hline BIC & -285.757 & -291.195 & -211.778 & & & \\
\hline
\end{tabular}

Table B1. OLS regressions on contributions across treatments

Notes: The dependent variable is a group's average contribution in round $t$, i.e. 80 observations from eight independent groups playing ten rounds. All specifications include the round of each contribution (coded as $t-1$ ) as well as the constant (equivalent to the estimated first-round contribution) as independent variables. The table reports coefficients. Robust standard errors are given in parentheses. $p$-values are given in square brackets. ${ }^{*} p<0.10,{ }^{* *} p<0.05,{ }^{* * *} p$ $<0.01$. 


\begin{tabular}{|c|c|c|c|c|}
\hline Round 1 & "60-0.02 & "60-0.04 & $10100-0.02$ & $100-0.04$ \\
\hline $8-0.25$ & 0.000 & 0.000 & 0.000 & 0.103 \\
\hline$n$ & 544 & 544 & 861 & 827 \\
\hline $60-0.02$ & & 0.000 & 0.000 & 0.000 \\
\hline$n$ & & & 1277 & 1243 \\
\hline $60-0.04$ & & & 0.000 & 0.000 \\
\hline$n$ & & & 1277 & 1243 \\
\hline $100-0.02$ & & & & 0.000 \\
\hline$n$ & & & & 1560 \\
\hline \multicolumn{5}{|l|}{ Round 10} \\
\hline $8-0.25$ & 0.012 & 0.207 & 0.012 & 0.074 \\
\hline$n$ & 16 & 16 & 16 & 16 \\
\hline $60-0.02$ & & 0.002 & 0.059 & 0.001 \\
\hline$n$ & & 16 & 16 & 16 \\
\hline $60-0.04$ & & & 0.009 & 0.528 \\
\hline$n$ & & & 16 & 16 \\
\hline $100-0.02$ & & & & 0.001 \\
\hline $\mathrm{n}$ & & & & 16 \\
\hline \multicolumn{5}{|l|}{ All rounds } \\
\hline $8-0.25$ & 0.012 & 0.012 & 0.012 & 0.208 \\
\hline$n$ & 16 & 16 & 16 & 16 \\
\hline $60-0.02$ & & 0.001 & 0.046 & 0.001 \\
\hline$n$ & & 16 & 16 & 16 \\
\hline $60-0.04$ & & & 0.001 & 0.093 \\
\hline$n$ & & & 16 & 16 \\
\hline $100-0.02$ & & & & 0.001 \\
\hline$n$ & & & & 16 \\
\hline
\end{tabular}

Table B2. Testing cooperation between treatments 8-0.25, 60-0.02, 60-0.04, 100-0.02, and 100-0.04.

Notes: Comparison tests between treatments 8-0.25, 60-0.02, 60-0.04, 100-0.02, and 100-0.04. The table shows the two-sided P-values from Mann-Whitney $U$ tests as well as the sample size $\mathrm{n}$. Tests for round 1 are based on individual contributions while tests for round 10 and for the averages over all rounds are based on group means.

Bold: significant differences, Bold: significant accounting for multi-testing (i.e. passing the 5\% threshold after Bonferroni correction for comparing one treatment to four other treatments $p<0.0125=0.05 / 4$ ). 


\begin{tabular}{|c|c|c|c|c|}
\hline & $\begin{array}{c}(1) \\
M P C R=0.02\end{array}$ & $\begin{array}{c}(2) \\
M P C R=0.04 \\
\end{array}$ & $\begin{array}{c}(3) \\
N=60 \\
\end{array}$ & $\begin{array}{c}(4) \\
N=100 \\
\end{array}$ \\
\hline$t-1$ & $\begin{array}{c}-0.023 * * * \\
(0.002)\end{array}$ & $\begin{array}{c}-0.032 * * * \\
(0.001)\end{array}$ & $\begin{array}{c}-0.023 * * * \\
(0.002)\end{array}$ & $\begin{array}{c}-0.030 * * * \\
(0.002)\end{array}$ \\
\hline$N=100$ & $\begin{array}{c}0.052 * * * \\
(0.015)\end{array}$ & $\begin{array}{c}0.040 * * * \\
(0.012)\end{array}$ & & \\
\hline$t-1 * N=100$ & $\begin{array}{c}-0.007 * * * \\
(0.002)\end{array}$ & $\begin{array}{l}-0.003 \\
(0.002)\end{array}$ & & \\
\hline$M P C R=0.04$ & & & $\begin{array}{c}0.132 * * * \\
(0.012)\end{array}$ & $\begin{array}{c}0.120 * * * \\
(0.015)\end{array}$ \\
\hline$t-1 * M P C R=0.04$ & & & $\begin{array}{c}-0.009 * * * \\
(0.002)\end{array}$ & $\begin{array}{c}-0.006 * * \\
(0.002)\end{array}$ \\
\hline Constant & $\begin{array}{c}0.215^{* * *} \\
(0.010)\end{array}$ & $\begin{array}{c}0.347 * * * \\
(0.007)\end{array}$ & $\begin{array}{c}0.215^{* * *} \\
(0.010)\end{array}$ & $\begin{array}{c}0.268^{* * * *} \\
(0.011)\end{array}$ \\
\hline Observations & 160 & 160 & 160 & 160 \\
\hline R-squared & 0.811 & 0.889 & 0.880 & 0.885 \\
\hline AIC & -589.969 & -612.848 & -617.081 & -586.388 \\
\hline BIC & -577.668 & -600.547 & -604.780 & -574.087 \\
\hline
\end{tabular}

Table B3: OLS regressions on contributions in large groups (by $M P C R$ and group size)

Notes: The dependent variable is a group's average contribution in round $t$. We have 80 observations from eight independent groups playing ten rounds in two treatments each, differentiated by MPCR and group size. All specifications include the round of each contribution (coded as $t-1$ ) as well as the constant (equivalent to the estimated firstround contribution) as independent variables. We also include a dummy for $N=100$ and its interactions with the period $t-1$. The table reports coefficients. Robust standard errors are given in parentheses.

$* * * p<0.01, * * p<0.05, * p<0.1$. 


\section{Robustness Check I: $d$ without interaction term}

As a first robustness check, we also run a simplified d value model M5* which does not condition on the $\mathrm{d}$ level and has the same number of parameters as M1 to M4. As Table S9 shows, $d$ has a significant positive influence on both first-round and average contributions. With respect to first-round contributions, this model fits better than all the models except the MPC model M3 and the original model M5. With respect to average contributions, it fits better than all the models including M3 but worse than M5.

\begin{tabular}{lcc}
\hline \hline & $\begin{array}{c}\text { First-round } \\
\text { contributions } \\
\left(\mathrm{M} 5^{*}\right)\end{array}$ & $\begin{array}{c}\text { Average contri- } \\
\text { butions }\end{array}$ \\
& $d$ & $\left(\mathrm{M} 5^{*}\right)$ \\
& & $d$ \\
$d$ & $0.736^{* * *}$ & $1.082^{* * *}$ \\
& $(0.185)$ & $(0.188)$ \\
Constant & $0.317^{* * *}$ & $0.146^{* * *}$ \\
& $(0.010)$ & $(0.008)$ \\
& & 136 \\
Observations & 136 & 0.272 \\
R-squared & 0.139 & -276.350 \\
AIC & -267.086 & -270.524 \\
\hline
\end{tabular}

Table B4. d value regressions without interaction term. Robust standard errors in parentheses.

$$
* * * p<0.01, * * p<0.05, * p<0.1 \text {. }
$$




\section{Appendix C: Figures}
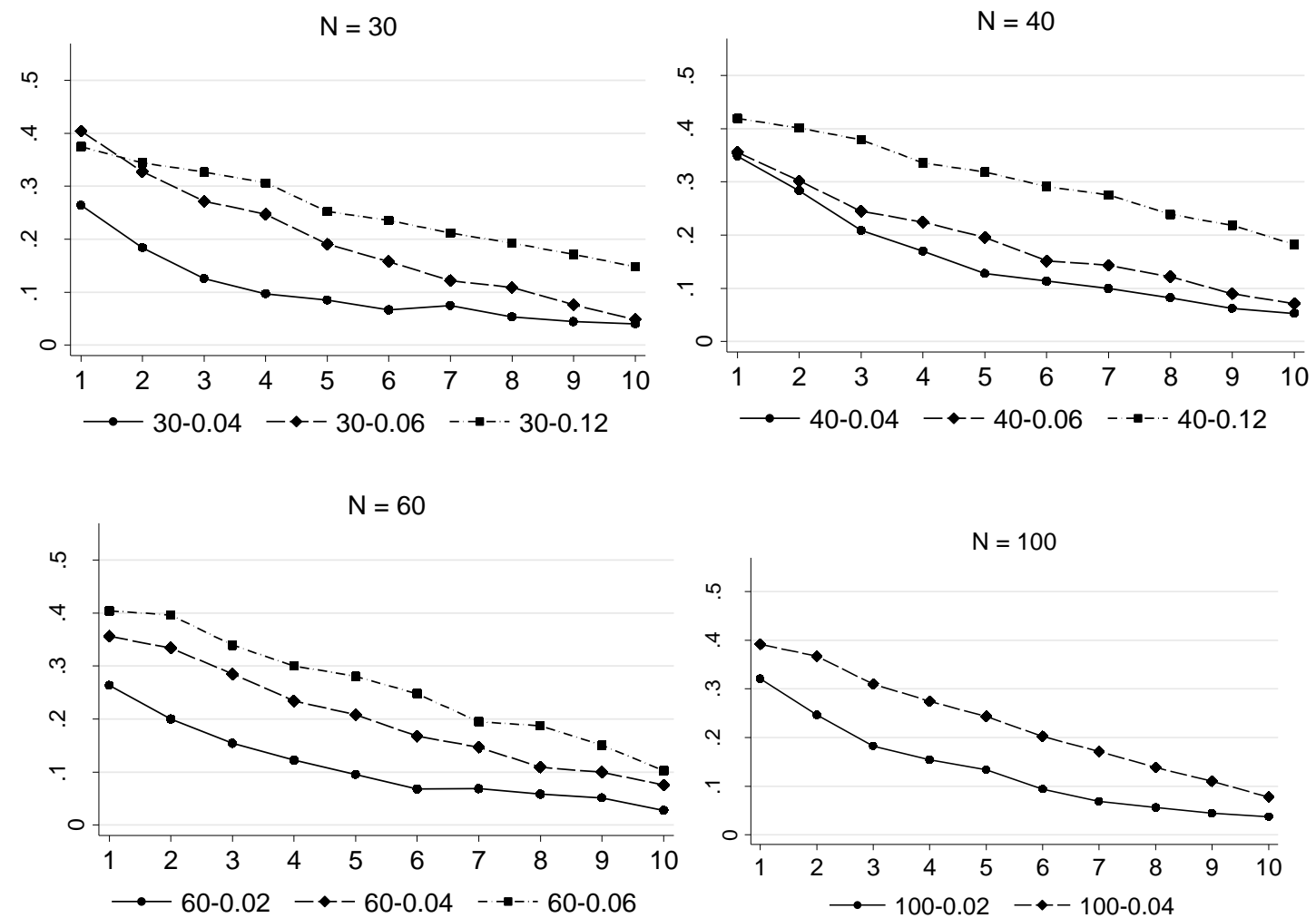

Figure C.1: Average share of contributions per round in groups with $N=30,40,60,100$

Notes: The graph shows the average share contribution in each round as share of the endowment for $N=30,40,60$, 100 and different $M P C R$-values. 
Appendix D: Regressions

OLS regressions based on group data

\begin{tabular}{|c|c|c|c|c|c|c|c|c|c|}
\hline & (1) & (2) & (3) & (4) & $(5)$ & (6) & (7) & (8) & (9) \\
\hline VARIABLES & $\mathrm{N}$ & $\mathrm{N}$ & $\mathrm{N}$ & MPCR & MPCR & MPCR & $\mathrm{d}$ & $\mathrm{d}$ & $\mathrm{d}$ \\
\hline $\mathrm{X}$ & -0.000 & -0.001 & -0.001 & $0.510 * * *$ & $1.515 * * *$ & 0.296 & $1.088 * * *$ & $3.898 * * *$ & $0.625 * *$ \\
\hline & $(0.000)$ & $(0.002)$ & $(0.000)$ & $(0.178)$ & $(0.426)$ & $(0.190)$ & $(0.246)$ & $(0.789)$ & $(0.295)$ \\
\hline$X^{2}$ & & $\begin{array}{c}0.000 \\
(0.000)\end{array}$ & & & $\begin{array}{c}-3.839 * * \\
(1.876)\end{array}$ & & & $\begin{array}{c}-23.241 * * * \\
(7.366)\end{array}$ & \\
\hline$I^{d<1 / N}$ & & & $-0.107 * * *$ & & & $-0.097 * * *$ & & & $-0.119 * * *$ \\
\hline & & & $(0.037)$ & & & $(0.034)$ & & & $(0.020)$ \\
\hline$I^{d<1 / N} * X$ & & & 0.001 & & & 0.913 & & & $6.111 * * *$ \\
\hline & & & $(0.001)$ & & & $(0.823)$ & & & (1.079) \\
\hline Constant & $\begin{array}{c}0.353 * * * \\
(0.020)\end{array}$ & $\begin{array}{c}0.366^{* * *} \\
(0.046)\end{array}$ & $\begin{array}{c}0.411 * * * \\
(0.024)\end{array}$ & $\begin{array}{c}0.315 * * * \\
(0.013)\end{array}$ & $\begin{array}{c}0.277 * * * \\
(0.017)\end{array}$ & $\begin{array}{c}0.354 * * * \\
(0.015)\end{array}$ & $\begin{array}{c}0.309 * * * \\
(0.010)\end{array}$ & $\begin{array}{c}0.267 * * * \\
(0.014)\end{array}$ & $\begin{array}{c}0.345 * * * \\
(0.014)\end{array}$ \\
\hline Observations & 104 & 104 & 104 & 104 & 104 & 104 & 104 & 104 & 104 \\
\hline R-squared & 0.000 & 0.003 & 0.211 & 0.138 & 0.175 & 0.247 & 0.242 & 0.345 & 0.410 \\
\hline $\mathrm{AIC}$ & -220.876 & -219.133 & -241.559 & -236.271 & -238.927 & -246.325 & -249.681 & -262.806 & -271.706 \\
\hline $\mathrm{BIC}$ & -215.587 & -211.200 & -230.982 & -230.982 & -230.993 & -235.747 & -244.393 & -254.872 & -261.128 \\
\hline
\end{tabular}

Table D1: OLS regression of group first-round contributions 


\begin{tabular}{|c|c|c|c|c|c|c|}
\hline & $(10)$ & $(11)$ & $(12)$ & (13) & (14) & (15) \\
\hline VARIABLES & $\mathrm{MPC}$ & MPC & MPC & $\mathrm{a}$ & $\mathrm{a}$ & $\mathrm{a}$ \\
\hline $\mathrm{X}$ & $\begin{array}{c}-0.002 * * * \\
(0.000)\end{array}$ & $\begin{array}{c}0.002 \\
(0.002)\end{array}$ & $\begin{array}{c}-0.002 \\
(0.001)\end{array}$ & $\begin{array}{c}0.037 * * * \\
(0.006)\end{array}$ & $\begin{array}{c}0.136^{* * *} \\
(0.029)\end{array}$ & $\begin{array}{l}0.019^{*} \\
(0.010)\end{array}$ \\
\hline$X^{2}$ & & $\begin{array}{c}-0.000 * * \\
(0.000)\end{array}$ & & & $\begin{array}{c}-0.018 * * * \\
(0.005)\end{array}$ & \\
\hline$I^{d<1 / N}$ & & & $\begin{array}{c}0.195 * * * \\
(0.063)\end{array}$ & & & $\begin{array}{c}-0.303 * * * \\
(0.060)\end{array}$ \\
\hline$I^{d<1 / N} * X$ & & & $-0.003 * *$ & & & $0.184 * * *$ \\
\hline Constant & $\begin{array}{c}0.464 * * * \\
(0.014)\end{array}$ & $\begin{array}{c}0.375 * * * \\
(0.044)\end{array}$ & $\begin{array}{c}(0.001) \\
0.435 * * * \\
(0.032)\end{array}$ & $\begin{array}{c}0.263 * * * \\
(0.017)\end{array}$ & $\begin{array}{c}0.148 * * * \\
(0.035)\end{array}$ & $\begin{array}{c}(0.036) \\
0.321 * * * \\
(0.035)\end{array}$ \\
\hline Observations & 104 & 104 & 104 & 104 & 104 & 104 \\
\hline R-squared & 0.347 & 0.378 & 0.403 & 0.250 & 0.308 & 0.404 \\
\hline $\mathrm{AIC}$ & -265.200 & -268.255 & -270.570 & -250.787 & -257.203 & -270.765 \\
\hline $\mathrm{BIC}$ & -259.911 & -260.322 & -259.992 & -245.498 & -249.270 & -260.188 \\
\hline
\end{tabular}

Table D1 continued 


\begin{tabular}{|c|c|c|c|c|c|c|c|c|c|}
\hline & (1) & (2) & (3) & (4) & $(5)$ & (6) & (7) & (8) & (9) \\
\hline VARIABLES & $\mathrm{N}$ & $\mathrm{N}$ & $\mathrm{N}$ & MPCR & MPCR & MPCR & $\mathrm{d}$ & d & d \\
\hline $\mathrm{X}$ & $\begin{array}{l}-0.000 \\
(0.000)\end{array}$ & $\begin{array}{c}-0.000 \\
(0.002)\end{array}$ & $\begin{array}{c}-0.001 * * * \\
(0.000)\end{array}$ & $\begin{array}{c}0.692 * * * \\
(0.166)\end{array}$ & $\begin{array}{c}2.458 * * * \\
(0.334)\end{array}$ & $\begin{array}{c}0.432 * * \\
(0.174)\end{array}$ & $\begin{array}{c}1.467 * * * \\
(0.221)\end{array}$ & $\begin{array}{c}4.519 * * * \\
(0.608)\end{array}$ & $\begin{array}{c}1.016^{* * *} \\
(0.269)\end{array}$ \\
\hline$X^{2}$ & & $\begin{array}{c}0.000 \\
(0.000)\end{array}$ & & & $\begin{array}{c}-6.744 * * * \\
(1.537)\end{array}$ & & & $\begin{array}{c}-25.244 * * * \\
(5.941)\end{array}$ & \\
\hline$I^{d<1 / N}$ & & & $\begin{array}{c}-0.143 * * * \\
(0.027)\end{array}$ & & & $\begin{array}{c}-0.100 * * * \\
(0.021)\end{array}$ & & & $\begin{array}{c}-0.087 * * * \\
(0.015)\end{array}$ \\
\hline$I^{d<1 / N} * X$ & & & $0.001^{*}$ & & & 0.589 & & & $3.019 * * *$ \\
\hline Constant & $\begin{array}{c}0.208 * * * \\
(0.018)\end{array}$ & $\begin{array}{c}0.212 * * * \\
(0.041)\end{array}$ & $\begin{array}{c}(0.000) \\
0.286^{* * *} \\
(0.022)\end{array}$ & $\begin{array}{c}0.145 * * * \\
(0.011)\end{array}$ & $\begin{array}{c}0.077 * * * \\
(0.013)\end{array}$ & $\begin{array}{c}(0.459) \\
0.194 * * * \\
(0.014)\end{array}$ & $\begin{array}{c}0.137 * * * \\
(0.008)\end{array}$ & $\begin{array}{c}0.091 * * * \\
(0.009)\end{array}$ & $\begin{array}{c}(0.588) \\
0.175 * * * \\
(0.013)\end{array}$ \\
\hline Observations & 104 & 104 & 104 & 104 & 104 & 104 & 104 & 104 & 104 \\
\hline R-squared & 0.009 & 0.010 & 0.452 & 0.285 & 0.416 & 0.477 & 0.494 & 0.630 & 0.586 \\
\hline $\mathrm{AIC}$ & -233.917 & -231.945 & -291.419 & -267.802 & -286.811 & -296.280 & -303.756 & -334.282 & -320.690 \\
\hline $\mathrm{BIC}$ & -228.628 & -224.012 & -280.842 & -262.513 & -278.877 & -285.703 & -298.467 & -326.349 & -310.112 \\
\hline
\end{tabular}

Table D2: OLS regression of group average contributions 


\begin{tabular}{|c|c|c|c|c|c|c|}
\hline & (10) & (11) & (12) & (13) & (14) & (15) \\
\hline VARIABLES & MPC & MPC & MPC & $\mathrm{a}$ & $\mathrm{a}$ & $\mathrm{a}$ \\
\hline $\mathrm{X}$ & $\begin{array}{c}-0.003 * * * \\
(0.000)\end{array}$ & $\begin{array}{c}-0.004 * * \\
(0.002)\end{array}$ & $\begin{array}{c}-0.003 * * * \\
(0.001)\end{array}$ & $\begin{array}{c}0.049 * * * \\
(0.004)\end{array}$ & $\begin{array}{c}0.101 * * * \\
(0.024)\end{array}$ & $\begin{array}{c}0.035 * * * \\
(0.010)\end{array}$ \\
\hline$X^{2}$ & & $\begin{array}{c}0.000 \\
(0.000)\end{array}$ & & & $\begin{array}{c}-0.009 * * \\
(0.005)\end{array}$ & \\
\hline$I^{d<1 / N}$ & & & $\begin{array}{l}-0.023 \\
(0.045)\end{array}$ & & & $\begin{array}{c}-0.145 * * * \\
(0.046)\end{array}$ \\
\hline$I^{d<1 / N_{*}}$ & & & $\begin{array}{c}0.000 \\
(0.001)\end{array}$ & & & $\begin{array}{c}0.075 * * * \\
(0.023)\end{array}$ \\
\hline Constant & $\begin{array}{c}0.325 * * * \\
(0.012)\end{array}$ & $\begin{array}{c}0.353 * * * \\
(0.039)\end{array}$ & $\begin{array}{c}0.335 * * * \\
(0.031)\end{array}$ & $\begin{array}{c}0.076^{* * *} \\
(0.012)\end{array}$ & $\begin{array}{c}0.015 \\
(0.027)\end{array}$ & $\begin{array}{c}0.125 * * * \\
(0.035)\end{array}$ \\
\hline Observations & 104 & 104 & 104 & 104 & 104 & 104 \\
\hline R-squared & 0.524 & 0.527 & 0.525 & 0.497 & 0.515 & 0.541 \\
\hline $\mathrm{AIC}$ & -310.026 & -308.763 & -306.320 & -304.338 & -306.173 & -309.886 \\
\hline $\mathrm{BIC}$ & -304.737 & -300.830 & -295.742 & -299.050 & -298.239 & -299.309 \\
\hline
\end{tabular}

Table D2 continued 


\begin{tabular}{|c|c|c|c|c|c|c|c|c|c|}
\hline & (1) & (2) & (3) & (4) & $(5)$ & (6) & (7) & (8) & (9) \\
\hline VARIABLES & $\mathrm{N}$ & $\mathrm{N}$ & $\mathrm{N}$ & MPCR & MPCR & MPCR & $\mathrm{d}$ & d & d \\
\hline $\mathrm{X}$ & $\begin{array}{c}-0.000 * * \\
(0.000)\end{array}$ & $\begin{array}{c}-0.000 \\
(0.001)\end{array}$ & $\begin{array}{c}-0.001 * * * \\
(0.000)\end{array}$ & $\begin{array}{c}0.525 * * * \\
(0.152)\end{array}$ & $\begin{array}{c}2.090 * * * \\
(0.295)\end{array}$ & $\begin{array}{c}0.381 * * \\
(0.160)\end{array}$ & $\begin{array}{c}1.098^{* * *} * \\
(0.202)\end{array}$ & $\begin{array}{c}2.658 * * * \\
(0.519)\end{array}$ & $\begin{array}{c}0.944 * * * \\
(0.248)\end{array}$ \\
\hline$X^{2}$ & & $\begin{array}{l}-0.000 \\
(0.000)\end{array}$ & & & $\begin{array}{c}-5.976 * * * \\
(1.377)\end{array}$ & & & $\begin{array}{c}-12.901 * * \\
(5.243)\end{array}$ & \\
\hline$I^{d<1 / N}$ & & & $-0.103 * * *$ & & & $-0.045 * * *$ & & & -0.018 \\
\hline$I^{d<1 / N} * X$ & & & $\begin{array}{c}(0.022) \\
0.001 * *\end{array}$ & & & $\begin{array}{c}(0.014) \\
0.026\end{array}$ & & & $\begin{array}{c}(0.012) \\
-0.161\end{array}$ \\
\hline Constant & $\begin{array}{c}0.101 * * * \\
(0.014)\end{array}$ & $\begin{array}{c}0.101 * * * \\
(0.032)\end{array}$ & $\begin{array}{c}(0.000) \\
0.156^{* * *} \\
(0.020)\end{array}$ & $\begin{array}{c}0.042 * * * \\
(0.009)\end{array}$ & $\begin{array}{c}-0.018 * \\
(0.010)\end{array}$ & $\begin{array}{c}(0.267) \\
0.070 * * * \\
(0.011)\end{array}$ & $\begin{array}{c}0.037 * * * \\
(0.006)\end{array}$ & $\begin{array}{c}0.013 * \\
(0.008)\end{array}$ & $\begin{array}{c}(0.472) \\
0.051 * * * \\
(0.010)\end{array}$ \\
\hline Observations & 104 & 104 & 104 & 104 & 104 & 104 & 104 & 104 & 104 \\
\hline R-squared & 0.041 & 0.041 & 0.403 & 0.280 & 0.455 & 0.393 & 0.472 & 0.533 & 0.490 \\
\hline $\mathrm{AIC}$ & -292.822 & -290.823 & -338.217 & -322.616 & -349.612 & -336.342 & -354.931 & -365.605 & -354.514 \\
\hline $\mathrm{BIC}$ & -287.533 & -282.890 & -327.640 & -317.328 & -341.679 & -325.764 & -349.643 & -357.672 & -343.936 \\
\hline
\end{tabular}

Table D3: OLS regression of group last-round contributions 


\begin{tabular}{|c|c|c|c|c|c|c|}
\hline & $(10)$ & (11) & (12) & (13) & (14) & (15) \\
\hline VARIABLES & MPC & $\mathrm{MPC}$ & MPC & $\mathrm{a}$ & $\mathrm{a}$ & $\mathrm{a}$ \\
\hline $\mathrm{X}$ & $\begin{array}{c}-0.002 * * * \\
(0.000)\end{array}$ & $\begin{array}{c}-0.005 * * * \\
(0.002)\end{array}$ & $\begin{array}{c}-0.002 * * * \\
(0.001)\end{array}$ & $\begin{array}{c}0.033^{* * *} * \\
(0.004)\end{array}$ & $\begin{array}{c}0.014 \\
(0.022)\end{array}$ & $\begin{array}{c}0.030^{* * *} \\
(0.009)\end{array}$ \\
\hline$X^{2}$ & & $\begin{array}{c}0.000 * * \\
(0.000)\end{array}$ & & & $\begin{array}{c}0.003 \\
(0.004)\end{array}$ & \\
\hline$I^{d<1 / N}$ & & & $\begin{array}{c}-0.118 * * * \\
(0.037)\end{array}$ & & & $\begin{array}{c}0.008 \\
(0.036)\end{array}$ \\
\hline$I^{d<1 / N_{*}} X$ & & & $\begin{array}{c}0.002 * * \\
(0.001)\end{array}$ & & & $\begin{array}{l}-0.014 \\
(0.016)\end{array}$ \\
\hline Constant & $\begin{array}{c}0.159 * * * \\
(0.012)\end{array}$ & $\begin{array}{c}0.237 * * * \\
(0.037)\end{array}$ & $\begin{array}{c}0.187 * * * \\
(0.029)\end{array}$ & $\begin{array}{l}-0.002 \\
(0.010)\end{array}$ & $\begin{array}{c}0.020 \\
(0.024)\end{array}$ & $\begin{array}{c}0.012 \\
(0.030)\end{array}$ \\
\hline Observations & 104 & 104 & 104 & 104 & 104 & 104 \\
\hline R-squared & 0.334 & 0.379 & 0.373 & 0.399 & 0.403 & 0.407 \\
\hline $\mathrm{AIC}$ & -330.773 & -336.074 & -333.062 & -341.459 & -340.178 & -338.758 \\
\hline $\mathrm{BIC}$ & -325.484 & -328.141 & -322.485 & -336.171 & -332.245 & -328.180 \\
\hline
\end{tabular}

Table D3 continued 


\section{OLS regressions based on individual data}

\begin{tabular}{|c|c|c|c|c|c|c|c|c|c|}
\hline & (1) & (2) & (3) & (4) & (5) & (6) & (7) & (8) & (9) \\
\hline VARIABLES & $\mathrm{N}$ & $\mathrm{N}$ & $\mathrm{N}$ & MPCR & MPCR & MPCR & $\mathrm{d}$ & $\mathrm{d}$ & $\mathrm{d}$ \\
\hline $\mathrm{X}$ & $\begin{array}{c}0.000 \\
(0.000)\end{array}$ & $\begin{array}{c}0.001 \\
(0.002)\end{array}$ & $\begin{array}{l}-0.001 * \\
(0.000)\end{array}$ & $\begin{array}{c}0.729 * * * \\
(0.161)\end{array}$ & $\begin{array}{c}1.836^{* * *} \\
(0.416)\end{array}$ & $\begin{array}{c}0.486^{* * *} \\
(0.175)\end{array}$ & $\begin{array}{c}1.296^{* * *} \\
(0.209)\end{array}$ & $\begin{array}{c}4.648 * * * \\
(0.684)\end{array}$ & $\begin{array}{c}0.835^{* * *} \\
(0.246)\end{array}$ \\
\hline $\mathrm{X}^{2}$ & & $\begin{array}{l}-0.000 \\
(0.000)\end{array}$ & & & $\begin{array}{c}-5.591 * * * \\
(1.863)\end{array}$ & & & $\begin{array}{c}-32.189 * * * \\
(6.300)\end{array}$ & \\
\hline$I^{d<1 / N}$ & & & $\begin{array}{c}-0.098 * * * \\
(0.032)\end{array}$ & & & $\begin{array}{c}-0.086 * * * \\
(0.032)\end{array}$ & & & $\begin{array}{c}-0.099 * * * \\
(0.020)\end{array}$ \\
\hline$I^{d<1 / N_{*}} X$ & & & 0.001 & & & 0.968 & & & $5.633 * * *$ \\
\hline Constant & $\begin{array}{c}0.200 * * * \\
(0.036)\end{array}$ & $\begin{array}{c}0.185 * * * \\
(0.054)\end{array}$ & $\begin{array}{c}(0.001) \\
0.260 * * * \\
(0.037)\end{array}$ & $\begin{array}{c}0.162 * * * \\
(0.038)\end{array}$ & $\begin{array}{c}0.123 * * * \\
(0.038)\end{array}$ & $\begin{array}{c}(0.752) \\
0.192 * * * \\
(0.040)\end{array}$ & $\begin{array}{c}0.160 * * * \\
(0.037)\end{array}$ & $\begin{array}{c}0.108 * * * \\
(0.034)\end{array}$ & $\begin{array}{c}(1.055) \\
0.186 * * * \\
(0.040)\end{array}$ \\
\hline Observations & 4,904 & 4,904 & 4,904 & 4,904 & 4,904 & 4,904 & 4,904 & 4,904 & 4,904 \\
\hline R-squared & 0.006 & 0.006 & 0.016 & 0.013 & 0.016 & 0.019 & 0.019 & 0.027 & 0.027 \\
\hline $\mathrm{AIC}$ & 2474.101 & 2475.740 & 2428.193 & 2436.990 & 2424.899 & 2411.971 & 2408.761 & 2369.889 & 2372.871 \\
\hline $\mathrm{BIC}$ & 2519.586 & 2527.722 & 2486.673 & 2482.475 & 2476.882 & 2470.451 & 2454.245 & 2421.872 & 2431.351 \\
\hline
\end{tabular}

Table D4: OLS regression of individual first-round contributions 


\begin{tabular}{lcccccc}
\hline & $(10)$ & $(11)$ & $(12)$ & $(13)$ & $(14)$ & $(15)$ \\
VARIABLES & MPC & MPC & MPC & $\mathrm{a}$ & $\mathrm{a}$ & $\mathrm{a}$ \\
\hline $\mathrm{X}$ & $-0.002^{* * *}$ & -0.002 & $-0.003^{* * *}$ & $0.039^{* * *}$ & $0.106^{* * *}$ & $0.035^{* * *}$ \\
& $(0.000)$ & $(0.002)$ & $(0.001)$ & $(0.005)$ & $(0.026)$ & $(0.007)$ \\
$\mathrm{X}^{2}$ & & -0.000 & & & $-0.012^{* * *}$ & \\
& & $(0.000)$ & & & $(0.004)$ & $-0.190^{* * *}$ \\
$I^{d<1 / N}$ & & & 0.097 & & & $(0.056)$ \\
& & & $(0.061)$ & & & \\
$I^{d<1 / N_{*} *}$ & & & -0.001 & & & \\
& & & $(0.001)$ & & & \\
Constant & $0.306^{* * *}$ & $0.293^{* * *}$ & $0.331^{* * *}$ & $0.099^{* * *}$ & 0.022 & $0.113^{* * *}$ \\
& $(0.038)$ & $(0.051)$ & $(0.044)$ & $(0.035)$ & $(0.041)$ & $(0.041)$ \\
Observations & & & & & & \\
R-squared & 4,904 & 4,904 & 4,904 & 4,904 & 4,904 & 4,904 \\
AIC & 0.027 & 0.028 & 0.030 & 0.025 & 0.026 & 0.030 \\
BIC & 2366.533 & 2368.281 & 2355.489 & 2380.494 & 2374.270 & 2360.088 \\
\hline & 2412.018 & 2420.263 & 2413.969 & 2425.978 & 2426.253 & 2418.569 \\
\hline
\end{tabular}

Table D4 continued 


\begin{tabular}{|c|c|c|c|c|c|c|c|c|c|}
\hline & (1) & (2) & (3) & $\begin{array}{c}(4) \\
M P C R\end{array}$ & $\begin{array}{c}(5) \\
M P C R\end{array}$ & $\begin{array}{c}(6) \\
M P C R\end{array}$ & (7) & (8) & (9) \\
\hline VARIABLES & & & & & MPCR & MPCR & $\mathrm{d}$ & $\mathrm{d}$ & $\mathrm{d}$ \\
\hline \multirow[t]{2}{*}{$\mathrm{X}$} & -0.000 & 0.001 & $-0.001 * * *$ & $1.085 * * *$ & $2.635 * * *$ & $0.850 * * *$ & $1.843 * * *$ & $5.007 * * *$ & $1.458 * * *$ \\
\hline & $(0.000)$ & $(0.001)$ & $(0.000)$ & $(0.159)$ & $(0.305)$ & $(0.178)$ & $(0.174)$ & $(0.466)$ & $(0.223)$ \\
\hline \multirow[t]{2}{*}{$X^{2}$} & & -0.000 & & & $-7.833 * * *$ & & & $-30.379 * * *$ & \\
\hline & & $(0.000)$ & & & $(1.422)$ & & & (4.532) & \\
\hline \multirow[t]{2}{*}{$I^{d<1 / N}$} & & & $-0.151 * * *$ & & & $-0.068 * * *$ & & & $-0.064 * * *$ \\
\hline & & & $(0.024)$ & & & $(0.019)$ & & & $(0.014)$ \\
\hline \multirow[t]{2}{*}{$I^{d<1 / N_{*}} *$} & & & $0.001 * *$ & & & 0.179 & & & $2.335 * * *$ \\
\hline & & & $(0.000)$ & & & $(0.411)$ & & & $(0.537)$ \\
\hline \multirow[t]{2}{*}{ Constant } & $0.112 * * *$ & 0.066 & $0.202 * * *$ & $0.039 * *$ & -0.015 & $0.074 * * *$ & $0.039 * *$ & -0.010 & $0.065 * * *$ \\
\hline & $(0.022)$ & $(0.040)$ & $(0.025)$ & $(0.019)$ & $(0.019)$ & $(0.022)$ & $(0.017)$ & $(0.016)$ & $(0.020)$ \\
\hline Observations & 4,904 & 4,904 & 4,904 & 4,904 & 4,904 & 4,904 & 4,904 & 4,904 & 4,904 \\
\hline R-squared & 0.019 & 0.022 & 0.092 & 0.077 & 0.096 & 0.105 & 0.112 & 0.138 & 0.124 \\
\hline AIC & -3803.975 & -3813.875 & -4179.392 & -4098.630 & -4202.488 & -4246.557 & -4291.016 & -4433.240 & -4352.031 \\
\hline $\mathrm{BIC}$ & -3758.491 & -3761.893 & -4120.912 & -4053.145 & -4150.506 & -4188.077 & -4245.532 & -4381.258 & -4293.551 \\
\hline
\end{tabular}

Table D5: OLS regression of individual average contributions 


\begin{tabular}{|c|c|c|c|c|c|c|}
\hline & $(10)$ & $(11)$ & $(12)$ & (13) & (14) & (15) \\
\hline VARIABLES & $\mathrm{MPC}$ & $\mathrm{MPC}$ & $\mathrm{MPC}$ & $\mathrm{a}$ & $\mathrm{a}$ & $\mathrm{a}$ \\
\hline $\mathrm{X}$ & $\begin{array}{c}-0.003 * * * \\
(0.000)\end{array}$ & $\begin{array}{c}-0.007 * * * \\
(0.001)\end{array}$ & $\begin{array}{c}-0.005 * * * \\
(0.001)\end{array}$ & $\begin{array}{c}0.050^{* * *} \\
(0.004)\end{array}$ & $\begin{array}{c}0.071 * * * \\
(0.021)\end{array}$ & $\begin{array}{c}0.050^{* * *} \\
(0.007)\end{array}$ \\
\hline $\mathrm{X}^{2}$ & & $\begin{array}{c}0.000 * * * \\
(0.000)\end{array}$ & & & $\begin{array}{c}-0.004 \\
(0.004)\end{array}$ & \\
\hline$I^{d<1 / N}$ & & & $\begin{array}{c}-0.095 * * \\
(0.038)\end{array}$ & & & $\begin{array}{c}-0.048 \\
(0.035)\end{array}$ \\
\hline$I^{d<1 / N} * X$ & & & $\begin{array}{c}0.003 * * * \\
(0.001)\end{array}$ & & & $\begin{array}{c}0.036 \\
(0.022)\end{array}$ \\
\hline Constant & $\begin{array}{c}0.219 * * * \\
(0.018)\end{array}$ & $\begin{array}{c}0.306 * * * \\
(0.033)\end{array}$ & $\begin{array}{c}0.277 * * * \\
(0.024)\end{array}$ & $\begin{array}{c}-0.034 * \\
(0.018)\end{array}$ & $\begin{array}{c}-0.058 * * \\
(0.025)\end{array}$ & $\begin{array}{l}-0.036 \\
(0.027)\end{array}$ \\
\hline Observations & 4,904 & 4,904 & 4,904 & 4,904 & 4,904 & 4,904 \\
\hline R-squared & 0.119 & 0.127 & 0.131 & 0.128 & 0.128 & 0.129 \\
\hline $\mathrm{AIC}$ & -4331.688 & -4373.890 & -4393.666 & -4378.342 & -4379.479 & -4382.965 \\
\hline $\mathrm{BIC}$ & -4286.203 & -4321.907 & -4335.186 & -4332.858 & -4327.497 & -4324.485 \\
\hline
\end{tabular}

Table D5 continued 


\begin{tabular}{|c|c|c|c|c|c|c|c|c|c|}
\hline & (1) & (2) & (3) & (4) & $(5)$ & (6) & (7) & (8) & (9) \\
\hline VARIABLES & $\mathrm{N}$ & $\mathrm{N}$ & $\mathrm{N}$ & MPCR & MPCR & MPCR & d & d & d \\
\hline $\mathrm{X}$ & $\begin{array}{c}-0.000 * * * \\
(0.000)\end{array}$ & $\begin{array}{c}0.000 \\
(0.001)\end{array}$ & $\begin{array}{c}-0.001 * * * \\
(0.000)\end{array}$ & $\begin{array}{c}0.880 * * * \\
(0.140)\end{array}$ & $\begin{array}{c}1.975 * * * \\
(0.254)\end{array}$ & $\begin{array}{c}0.783 * * * \\
(0.148)\end{array}$ & $\begin{array}{c}1.407 * * * \\
(0.147)\end{array}$ & $\begin{array}{c}2.291 * * * \\
(0.328)\end{array}$ & $\begin{array}{c}1.326^{* * * *} \\
(0.174)\end{array}$ \\
\hline$X^{2}$ & & $\begin{array}{l}-0.000 \\
(0.000)\end{array}$ & & & $\begin{array}{c}-5.534 * * * \\
(1.206)\end{array}$ & & & $\begin{array}{c}-8.488 * * \\
(3.548)\end{array}$ & \\
\hline$I^{d<1 / N}$ & & & $-0.111 * * *$ & & & $-0.020 *$ & & & -0.006 \\
\hline$I^{d<1 / N} * X$ & & & $\begin{array}{c}(0.018) \\
0.001 * * *\end{array}$ & & & $\begin{array}{c}(0.011) \\
-0.312\end{array}$ & & & $\begin{array}{c}(0.008) \\
-0.400\end{array}$ \\
\hline & & & $(0.000)$ & & & $(0.235)$ & & & $(0.419)$ \\
\hline Constant & $\begin{array}{c}0.027 \\
(0.018)\end{array}$ & $\begin{array}{c}0.011 \\
(0.029)\end{array}$ & $\begin{array}{c}0.091 * * * \\
(0.021)\end{array}$ & $\begin{array}{c}-0.045^{* * *} * \\
(0.017)\end{array}$ & $\begin{array}{c}-0.084 * * * \\
(0.018)\end{array}$ & $\begin{array}{l}-0.028 \\
(0.018)\end{array}$ & $\begin{array}{c}-0.042 * * * \\
(0.016)\end{array}$ & $\begin{array}{c}-0.056^{* * *} \\
(0.016)\end{array}$ & $\begin{array}{c}-0.035 * * \\
(0.017)\end{array}$ \\
\hline Observations & 4,904 & 4,904 & 4,904 & 4,904 & 4,904 & 4,904 & 4,904 & 4,904 & 4,904 \\
\hline R-squared & 0.017 & 0.017 & 0.047 & 0.046 & 0.054 & 0.053 & 0.060 & 0.062 & 0.061 \\
\hline $\mathrm{AIC}$ & -3106.410 & -3105.696 & -3256.597 & -3253.181 & -3295.376 & -3285.230 & -3326.484 & -3333.607 & -3326.455 \\
\hline $\mathrm{BIC}$ & -3060.925 & -3053.714 & -3198.117 & -3207.696 & -3243.394 & -3226.750 & -3280.999 & -3281.625 & -3267.975 \\
\hline
\end{tabular}

Table D6: OLS regression of individual last-round contributions 


\begin{tabular}{|c|c|c|c|c|c|c|}
\hline & $(10)$ & $(11)$ & $(12)$ & (13) & (14) & (15) \\
\hline VARIABLES & MPC & MPC & MPC & $\mathrm{a}$ & $\mathrm{a}$ & $\mathrm{a}$ \\
\hline $\mathrm{X}$ & $\begin{array}{c}-0.001 * * * \\
(0.000)\end{array}$ & $\begin{array}{c}-0.006^{* * *} \\
(0.001)\end{array}$ & $\begin{array}{c}-0.003 * * * \\
(0.000)\end{array}$ & $\begin{array}{c}0.031 * * * \\
(0.004)\end{array}$ & $\begin{array}{l}-0.008 \\
(0.020)\end{array}$ & $\begin{array}{c}0.035^{* * *} \\
(0.006)\end{array}$ \\
\hline$X^{2}$ & & $\begin{array}{c}0.000 * * * \\
(0.000)\end{array}$ & & & $\begin{array}{c}0.007 * \\
(0.004)\end{array}$ & \\
\hline$I^{d<1 / N}$ & & & $\begin{array}{c}-0.125 * * * \\
(0.029)\end{array}$ & & & $\begin{array}{l}0.041 * \\
(0.025)\end{array}$ \\
\hline$I^{d<1 / N} * X$ & & & $\begin{array}{c}0.003 * * * \\
(0.001)\end{array}$ & & & $\begin{array}{l}-0.022 \\
(0.014)\end{array}$ \\
\hline Constant & $\begin{array}{c}0.072 * * * \\
(0.019)\end{array}$ & $\begin{array}{c}0.161 * * * \\
(0.034)\end{array}$ & $\begin{array}{c}0.116^{* * *} \\
(0.025)\end{array}$ & $\begin{array}{c}-0.080 * * * \\
(0.017)\end{array}$ & $\begin{array}{l}-0.035 \\
(0.024)\end{array}$ & $\begin{array}{c}-0.093 * * * \\
(0.024)\end{array}$ \\
\hline Observations & 4,904 & 4,904 & 4,904 & 4,904 & 4,904 & 4,904 \\
\hline R-squared & 0.041 & 0.048 & 0.048 & 0.050 & 0.051 & 0.050 \\
\hline $\mathrm{AIC}$ & -3228.321 & -3263.221 & -3260.228 & -3273.738 & -3280.571 & -3272.887 \\
\hline $\mathrm{BIC}$ & -3182.836 & -3211.238 & -3201.747 & -3228.253 & -3228.589 & -3214.407 \\
\hline
\end{tabular}

Table D6 continued 
Tobit regressions based on group data

\begin{tabular}{|c|c|c|c|c|c|c|c|c|c|}
\hline & (1) & (2) & (3) & (4) & $(5)$ & (6) & (7) & (8) & (9) \\
\hline VARIABLES & $\mathrm{N}$ & $\mathrm{N}$ & $\mathrm{N}$ & MPCR & MPCR & MPCR & $\mathrm{d}$ & $\mathrm{d}$ & $\mathrm{d}$ \\
\hline \multirow[t]{2}{*}{$\mathrm{X}$} & -0.000 & -0.001 & -0.001 & $0.510 * * *$ & $1.515 * * *$ & 0.296 & $1.088 * * *$ & $3.898 * * *$ & $0.625 * *$ \\
\hline & $(0.000)$ & $(0.002)$ & $(0.000)$ & $(0.178)$ & $(0.426)$ & $(0.190)$ & $(0.246)$ & $(0.789)$ & $(0.295)$ \\
\hline \multirow[t]{2}{*}{$X^{2}$} & & 0.000 & & & $-3.839 * *$ & & & $-23.241 * * *$ & \\
\hline & & $(0.000)$ & & & $(1.876)$ & & & $(7.366)$ & \\
\hline \multirow[t]{2}{*}{$I^{d<1 / N}$} & & & $-0.107 * * *$ & & & $-0.097 * * *$ & & & $-0.119 * * *$ \\
\hline & & & $(0.037)$ & & & $(0.034)$ & & & $(0.020)$ \\
\hline \multirow[t]{2}{*}{$I^{d<1 / N_{* X}}$} & & & 0.001 & & & 0.913 & & & $6.111 * * *$ \\
\hline & & & $(0.001)$ & & & $(0.823)$ & & & (1.079) \\
\hline \multirow[t]{2}{*}{ Constant } & $0.353 * * *$ & $0.366^{* * *}$ & $0.411 * * *$ & $0.315 * * *$ & $0.277 * * *$ & $0.354 * * *$ & $0.309 * * *$ & $0.267 * * *$ & $0.345^{* * *}$ \\
\hline & $(0.020)$ & $(0.046)$ & $(0.024)$ & $(0.013)$ & $(0.017)$ & $(0.015)$ & $(0.010)$ & $(0.014)$ & $(0.014)$ \\
\hline Observations & 104 & 104 & 104 & 104 & 104 & 104 & 104 & 104 & 104 \\
\hline R-squared & 0.000 & 0.003 & 0.211 & 0.138 & 0.175 & 0.247 & 0.242 & 0.345 & 0.410 \\
\hline $\mathrm{AIC}$ & -220.876 & -219.133 & -241.559 & -236.271 & -238.927 & -246.325 & -249.681 & -262.806 & -271.706 \\
\hline $\mathrm{BIC}$ & -215.587 & -211.200 & -230.982 & -230.982 & -230.993 & -235.747 & -244.393 & -254.872 & -261.128 \\
\hline
\end{tabular}

Table D7: Tobit regression of group first-round contributions 


\begin{tabular}{lcccccc}
\hline & $(10)$ & $(11)$ & $(12)$ & $(13)$ & $(14)$ & $(15)$ \\
VARIABLES & MPC & MPC & MPC & $\mathrm{a}$ & $\mathrm{a}$ & $\mathrm{a}$ \\
\hline $\mathrm{X}$ & $-0.002^{* * *}$ & 0.002 & -0.002 & $0.037^{* * *}$ & $0.136^{* * *}$ & $0.019^{*}$ \\
& $(0.000)$ & $(0.002)$ & $(0.001)$ & $(0.005)$ & $(0.029)$ & $(0.010)$ \\
$\mathrm{X}^{2}$ & & $-0.000^{* *}$ & & & $-0.018^{* * *}$ & \\
& & $(0.000)$ & & & $(0.005)$ & $-0.303^{* * *}$ \\
$I^{d<1 / N}$ & & & $0.195^{* * *}$ & & & $(0.059)$ \\
& & & $(0.062)$ & & & $0.184^{* * *}$ \\
$I^{d<1 / N * X}$ & & & $-0.003^{* *}$ & & & $(0.036)$ \\
& & & $(0.001)$ & & & $0.321^{* * *}$ \\
Constant & $0.464^{* * *}$ & $0.375^{* * *}$ & $0.435^{* * *}$ & $0.263^{* * *}$ & $0.148^{* * *}$ & $(0.035)$ \\
& $(0.014)$ & $(0.043)$ & $(0.032)$ & $(0.017)$ & $(0.035)$ & \\
Observations & & & & & & 104 \\
AIC & 104 & 104 & 104 & 104 & -255.203 & -268.765 \\
BIC & -263.200 & -266.255 & -268.570 & -248.787 & -255 \\
\hline
\end{tabular}

Table D7 continued 


\begin{tabular}{|c|c|c|c|c|c|c|c|c|c|}
\hline & (1) & (2) & (3) & (4) & $(5)$ & (6) & (7) & $(8)$ & (9) \\
\hline VARIABLES & $\mathrm{N}$ & $\mathrm{N}$ & $\mathrm{N}$ & MPCR & MPCR & MPCR & $\mathrm{d}$ & $\mathrm{d}$ & $\mathrm{d}$ \\
\hline $\mathrm{X}$ & $\begin{array}{l}-0.000 \\
(0.000)\end{array}$ & $\begin{array}{c}-0.000 \\
(0.002)\end{array}$ & $\begin{array}{c}-0.001 * * * \\
(0.000)\end{array}$ & $\begin{array}{c}0.692 * * * \\
(0.165)\end{array}$ & $\begin{array}{c}2.458 * * * \\
(0.331)\end{array}$ & $\begin{array}{c}0.432 * * \\
(0.172)\end{array}$ & $\begin{array}{c}1.467 * * * \\
(0.220)\end{array}$ & $\begin{array}{c}4.519 * * * \\
(0.602)\end{array}$ & $\begin{array}{c}1.016^{* * *} \\
(0.265)\end{array}$ \\
\hline$X^{2}$ & & $\begin{array}{c}0.000 \\
(0.000)\end{array}$ & & & $\begin{array}{c}-6.744 * * * \\
(1.522)\end{array}$ & & & $\begin{array}{c}-25.244 * * * \\
(5.883)\end{array}$ & \\
\hline$I^{d<1 / N}$ & & & $\begin{array}{c}-0.143 * * * \\
(0.027)\end{array}$ & & & $\begin{array}{c}-0.100 * * * \\
(0.021)\end{array}$ & & & $\begin{array}{c}-0.087 * * * \\
(0.015)\end{array}$ \\
\hline$I^{d<1 / N_{* X}}$ & & & $\begin{array}{l}0.001 * \\
(0.000)\end{array}$ & & & $\begin{array}{c}0.589 \\
(0.452)\end{array}$ & & & $\begin{array}{c}3.019 * * * \\
(0.579)\end{array}$ \\
\hline Constant & $\begin{array}{c}0.208 * * * \\
(0.018)\end{array}$ & $\begin{array}{c}0.212 * * * \\
(0.040)\end{array}$ & $\begin{array}{c}0.286 * * * \\
(0.021)\end{array}$ & $\begin{array}{c}0.145 * * * \\
(0.011)\end{array}$ & $\begin{array}{c}0.077 * * * \\
(0.013)\end{array}$ & $\begin{array}{c}0.194 * * * \\
(0.014)\end{array}$ & $\begin{array}{c}0.137 * * * \\
(0.008)\end{array}$ & $\begin{array}{c}0.091 * * * \\
(0.009)\end{array}$ & $\begin{array}{c}0.175 * * * \\
(0.013)\end{array}$ \\
\hline Observations & 104 & 104 & 104 & 104 & 104 & 104 & 104 & 104 & 104 \\
\hline $\mathrm{AIC}$ & -231.917 & -229.945 & -289.419 & -265.802 & -284.811 & -294.280 & -301.756 & -332.282 & -318.690 \\
\hline $\mathrm{BIC}$ & -223.983 & -219.367 & -276.197 & -257.869 & -274.233 & -281.059 & -293.823 & -321.705 & -305.468 \\
\hline
\end{tabular}

Table D8: Tobit regression of group average contributions 


\begin{tabular}{lcccccc}
\hline & $(10)$ & $(11)$ & $(12)$ & $(13)$ & $(14)$ & $(15)$ \\
VARIABLES & MPC & MPC & MPC & $\mathrm{a}$ & $\mathrm{a}$ & $\mathrm{a}$ \\
\hline $\mathrm{X}$ & $-0.003^{* * *}$ & $-0.004^{* *}$ & $-0.003^{* * *}$ & $0.049^{* * *}$ & $0.101^{* * *}$ & $0.035^{* * *}$ \\
& $(0.000)$ & $(0.002)$ & $(0.001)$ & $(0.004)$ & $(0.024)$ & $(0.010)$ \\
$\mathrm{X}^{2}$ & & 0.000 & & & $-0.009^{* *}$ & \\
& & $(0.000)$ & & & $(0.004)$ & $-0.145^{* * *}$ \\
$I^{d<1 / N}$ & & & -0.023 & & & $(0.045)$ \\
& & & $(0.044)$ & & & $0.075^{* * *}$ \\
$I^{d<1 / N *} X$ & & & 0.000 & & & $(0.023)$ \\
& & & $(0.001)$ & & & $0.025^{* * *}$ \\
Constant & $0.325^{* * *}$ & $0.353^{* * *}$ & $0.335^{* * *}$ & $0.076^{* * *}$ & 0.015 & $0.034)$ \\
& $(0.012)$ & $(0.038)$ & $(0.031)$ & $(0.012)$ & $(0.026)$ & $(0.034)$ \\
Observations & 104 & 104 & & & & \\
AIC & -308.026 & -306.763 & -304.320 & -302.338 & -304.173 & -307.886 \\
BIC & -300.093 & -296.186 & -291.098 & -294.405 & -293.595 & -294.664 \\
\hline
\end{tabular}

Table D8 continued 


\begin{tabular}{|c|c|c|c|c|c|c|c|c|c|}
\hline & (1) & (2) & (3) & (4) & $(5)$ & $(6)$ & (7) & (8) & (9) \\
\hline VARIABLES & $\mathrm{N}$ & $\mathrm{N}$ & $\mathrm{N}$ & MPCR & MPCR & MPCR & $\mathrm{d}$ & $\mathrm{d}$ & $\mathrm{d}$ \\
\hline $\mathrm{X}$ & $\begin{array}{c}-0.000^{* *} \\
(0.000)\end{array}$ & $\begin{array}{c}-0.000 \\
(0.001)\end{array}$ & $\begin{array}{c}-0.001 * * * \\
(0.000)\end{array}$ & $\begin{array}{c}0.519 * * * \\
(0.155)\end{array}$ & $\begin{array}{c}2.097 * * * \\
(0.295)\end{array}$ & $\begin{array}{c}0.375 * * \\
(0.161)\end{array}$ & $\begin{array}{c}1.092^{* * *} \\
(0.205)\end{array}$ & $\begin{array}{c}2.673 * * * \\
(0.522)\end{array}$ & $\begin{array}{c}0.936^{* * * *} \\
(0.249)\end{array}$ \\
\hline$X^{2}$ & & $\begin{array}{l}-0.000 \\
(0.000)\end{array}$ & & & $\begin{array}{c}-6.026 * * * \\
(1.389)\end{array}$ & & & $\begin{array}{c}-13.082 * * \\
(5.292)\end{array}$ & \\
\hline$I^{d<1 / N}$ & & & $-0.102 * * *$ & & & $-0.046 * * *$ & & & -0.018 \\
\hline$I^{d<1 / N_{*}} X$ & & & $\begin{array}{c}(0.022) \\
0.001 * *\end{array}$ & & & $\begin{array}{c}(0.014) \\
0.032\end{array}$ & & & $\begin{array}{c}(0.012) \\
-0.154\end{array}$ \\
\hline Constant & $\begin{array}{c}0.100 * * * \\
(0.014)\end{array}$ & $\begin{array}{c}0.098 * * * \\
(0.032)\end{array}$ & $\begin{array}{c}(0.000) \\
0.155^{* * *} \\
(0.020)\end{array}$ & $\begin{array}{c}0.042 * * * \\
(0.009)\end{array}$ & $\begin{array}{c}-0.018 * \\
(0.010)\end{array}$ & $\begin{array}{c}(0.265) \\
0.071 * * * \\
(0.011)\end{array}$ & $\begin{array}{c}0.037 * * * \\
(0.006)\end{array}$ & $\begin{array}{l}0.013 * \\
(0.008)\end{array}$ & $\begin{array}{c}(0.467) \\
0.051 * * * \\
(0.010)\end{array}$ \\
\hline Observations & 104 & 104 & 104 & 104 & 104 & 104 & 104 & 104 & 104 \\
\hline $\mathrm{AIC}$ & -283.674 & -281.688 & -327.565 & -312.046 & -339.010 & -325.534 & -343.766 & -354.552 & -343.338 \\
\hline $\mathrm{BIC}$ & -275.741 & -271.111 & -314.343 & -304.113 & -328.432 & -312.312 & -335.833 & -343.975 & -330.116 \\
\hline
\end{tabular}

Table D9: Tobit regression of group last-round contributions 


\begin{tabular}{lcccccc}
\hline & $(10)$ & $(11)$ & $(12)$ & $(13)$ & $(14)$ & $(15)$ \\
VARIABLES & MPC & MPC & MPC & $\mathrm{a}$ & $\mathrm{a}$ & $\mathrm{a}$ \\
\hline $\mathrm{X}$ & $-0.002^{* * *}$ & $-0.005^{* * *}$ & $-0.002^{* * *}$ & $0.034^{* * *}$ & 0.014 & $0.030^{* * *}$ \\
& $(0.000)$ & $(0.002)$ & $(0.001)$ & $(0.004)$ & $(0.022)$ & $(0.009)$ \\
$\mathrm{X}^{2}$ & & $0.000^{* *}$ & & & 0.004 & \\
& & $(0.000)$ & & & $(0.004)$ & 0.010 \\
$I^{d<1 / N}$ & & & $-0.119^{* * *}$ & & & $(0.036)$ \\
& & & $(0.036)$ & & & -0.015 \\
$I^{d<1 / N * X}$ & & & $0.002^{* *}$ & & & $(0.016)$ \\
& & & $(0.001)$ & & & 0.010 \\
Constant & $0.159^{* * *}$ & $0.239^{* * *}$ & $0.188^{* * *}$ & -0.002 & 0.021 & $(0.030)$ \\
& $(0.012)$ & $(0.037)$ & $(0.029)$ & $(0.010)$ & $(0.023)$ & \\
Observations & & & & & & 104 \\
AIC & 104 & 104 & 104 & 104 & 104 & -329.223 \\
BIC & -321.276 & -326.733 & -323.642 & -332.066 & -330.823 & -316.001 \\
\hline
\end{tabular}

Table D9 continued 
Tobit regressions based on individual data

\begin{tabular}{|c|c|c|c|c|c|c|c|c|c|}
\hline & (1) & (2) & (3) & (4) & (5) & (6) & (7) & (8) & (9) \\
\hline VARIABLES & $\mathrm{N}$ & $\mathrm{N}$ & $\mathrm{N}$ & MPCR & MPCR & MPCR & $\mathrm{d}$ & $\mathrm{d}$ & $\mathrm{d}$ \\
\hline $\mathrm{X}$ & $\begin{array}{c}-0.000 \\
(0.000)\end{array}$ & $\begin{array}{c}0.001 \\
(0.002)\end{array}$ & $\begin{array}{c}-0.001 * * \\
(0.000)\end{array}$ & $\begin{array}{c}1.006 * * * \\
(0.219)\end{array}$ & $\begin{array}{c}2.715 * * * \\
(0.548)\end{array}$ & $\begin{array}{c}0.700 * * * \\
(0.243)\end{array}$ & $\begin{array}{c}1.764 * * * \\
(0.272)\end{array}$ & $\begin{array}{c}6.402 * * * \\
(0.878)\end{array}$ & $\begin{array}{c}1.208 * * * \\
(0.332)\end{array}$ \\
\hline $\mathrm{X}^{2}$ & & $\begin{array}{l}-0.000 \\
(0.000)\end{array}$ & & & $\begin{array}{c}-8.651 * * * \\
(2.535)\end{array}$ & & & $\begin{array}{c}-44.539^{* * *} \\
(8.130)\end{array}$ & \\
\hline$I^{d<1 / N}$ & & & $-0.139 * * *$ & & & $-0.109 * *$ & & & $-0.125 * * *$ \\
\hline$I^{d<1 / N_{*}} X$ & & & $\begin{array}{c}(0.043) \\
0.001\end{array}$ & & & $\begin{array}{c}(0.043) \\
1.271\end{array}$ & & & $\begin{array}{c}(0.027) \\
7.445^{* * *}\end{array}$ \\
\hline Constant & $\begin{array}{c}0.135 * * * \\
(0.048)\end{array}$ & $\begin{array}{c}0.097 \\
(0.071)\end{array}$ & $\begin{array}{c}(0.001) \\
0.218 * * * \\
(0.048)\end{array}$ & $\begin{array}{c}0.074 \\
(0.050)\end{array}$ & $\begin{array}{c}0.014 \\
(0.050)\end{array}$ & $\begin{array}{c}(1.008) \\
0.111^{* *} \\
(0.053)\end{array}$ & $\begin{array}{c}0.073 \\
(0.048)\end{array}$ & $\begin{array}{l}-0.000 \\
(0.045)\end{array}$ & $\begin{array}{c}(1.414) \\
0.103 * * \\
(0.052)\end{array}$ \\
\hline Observations & 4,904 & 4,904 & 4,904 & 4,904 & 4,904 & 4,904 & 4,904 & 4,904 & 4,904 \\
\hline $\mathrm{AIC}$ & 6655.359 & 6656.115 & 6610.369 & 6616.608 & 6600.024 & 6596.095 & 6588.433 & 6547.238 & 6556.195 \\
\hline $\mathrm{BIC}$ & 6707.341 & 6714.595 & 6675.347 & 6668.591 & 6658.504 & 6661.073 & 6640.415 & 6605.718 & 6621.173 \\
\hline
\end{tabular}

Table D10: Tobit regression of individual first-round contributions 


\begin{tabular}{|c|c|c|c|c|c|c|}
\hline & $(10)$ & (11) & $(12)$ & (13) & (14) & (15) \\
\hline VARIABLES & MPC & MPC & MPC & $\mathrm{a}$ & $\mathrm{a}$ & $\mathrm{a}$ \\
\hline $\mathrm{X}$ & $\begin{array}{c}-0.003^{* * *} \\
(0.000)\end{array}$ & $\begin{array}{c}-0.003 \\
(0.002)\end{array}$ & $\begin{array}{c}-0.004 * * * \\
(0.001)\end{array}$ & $\begin{array}{c}0.051 * * * \\
(0.006)\end{array}$ & $\begin{array}{c}0.135 * * * \\
(0.034)\end{array}$ & $\begin{array}{c}0.049 * * * \\
(0.010)\end{array}$ \\
\hline $\mathrm{X}^{2}$ & & $\begin{array}{c}-0.000 \\
(0.000)\end{array}$ & & & $\begin{array}{c}-0.015 * * \\
(0.006)\end{array}$ & \\
\hline$I^{d<1 / N}$ & & & 0.121 & & & $-0.241 * * *$ \\
\hline$I^{d<1 / N_{*}} X$ & & & $\begin{array}{c}(0.081) \\
-0.000 \\
(0.001)\end{array}$ & & & $\begin{array}{c}(0.075) \\
0.168 * * * \\
(0.050)\end{array}$ \\
\hline Constant & $\begin{array}{c}0.267 * * * \\
(0.049)\end{array}$ & $\begin{array}{c}0.259 * * * \\
(0.065)\end{array}$ & $\begin{array}{c}0.309 * * * \\
(0.055)\end{array}$ & $\begin{array}{c}-0.007 \\
(0.047)\end{array}$ & $\begin{array}{c}-0.103 * \\
(0.054)\end{array}$ & $\begin{array}{c}0.002 \\
(0.056)\end{array}$ \\
\hline Observations & 4,904 & 4,904 & 4,904 & 4,904 & 4,904 & 4,904 \\
\hline $\mathrm{AIC}$ & 6552.622 & 6554.567 & 6539.149 & 6564.437 & 6559.382 & 6544.726 \\
\hline $\mathrm{BIC}$ & 6604.605 & 6613.047 & 6604.127 & 6616.419 & 6617.862 & 6609.704 \\
\hline
\end{tabular}

Table D10 continued 


\begin{tabular}{|c|c|c|c|c|c|c|c|c|c|}
\hline & (1) & (2) & (3) & $(4)$ & $(5)$ & $(6)$ & (7) & (8) & (9) \\
\hline VARIABLES & $\mathrm{N}$ & $\mathrm{N}$ & $\mathrm{N}$ & MPCR & MPCR & MPCR & $\mathrm{d}$ & $\mathrm{d}$ & $\mathrm{d}$ \\
\hline \multirow[t]{2}{*}{$\mathrm{X}$} & -0.000 & 0.002 & $-0.001 * * *$ & $1.163^{* * *}$ & $2.885 * * *$ & $0.908^{* * *}$ & $1.972 * * *$ & $5.492 * * *$ & $1.556^{* * *}$ \\
\hline & $(0.000)$ & $(0.002)$ & $(0.000)$ & $(0.171)$ & $(0.331)$ & $(0.192)$ & $(0.185)$ & $(0.501)$ & $(0.240)$ \\
\hline$X^{2}$ & & $\begin{array}{l}-0.000 \\
(0.000)\end{array}$ & & & $\begin{array}{c}-8.695 * * * \\
(1.553)\end{array}$ & & & $\begin{array}{c}-33.760 * * * \\
(4.847)\end{array}$ & \\
\hline \multirow[t]{2}{*}{$I^{d<1 / N}$} & & & $-0.164 * * *$ & & & $-0.075 * * *$ & & & $-0.071 * * *$ \\
\hline & & & $(0.027)$ & & & $(0.022)$ & & & $(0.015)$ \\
\hline \multirow[t]{2}{*}{$I^{d<1 / N_{*}} *$} & & & $0.001 * *$ & & & 0.240 & & & $2.714 * * *$ \\
\hline & & & $(0.000)$ & & & $(0.469)$ & & & $(0.590)$ \\
\hline \multirow[t]{2}{*}{ Constant } & $0.091 * * *$ & 0.037 & $0.188 * * *$ & 0.011 & $-0.049 * *$ & $0.049 * *$ & 0.012 & $-0.044 * *$ & $0.039^{*}$ \\
\hline & $(0.024)$ & $(0.044)$ & $(0.027)$ & $(0.021)$ & $(0.021)$ & $(0.024)$ & $(0.019)$ & $(0.018)$ & $(0.022)$ \\
\hline Observations & 4,904 & 4,904 & 4,904 & 4,904 & 4,904 & 4,904 & 4,904 & 4,904 & 4,904 \\
\hline AIC & -1210.044 & -1220.502 & -1556.668 & -1480.040 & -1582.553 & -1613.540 & -1656.738 & -1797.112 & -1714.651 \\
\hline $\mathrm{BIC}$ & -1158.062 & -1162.022 & -1491.690 & -1428.058 & -1524.072 & -1548.562 & -1604.756 & -1738.632 & -1649.673 \\
\hline
\end{tabular}

Table D11: Tobit regression of individual average contributions 


\begin{tabular}{|c|c|c|c|c|c|c|}
\hline & $(10)$ & (11) & (12) & (13) & (14) & $(15)$ \\
\hline VARIABLES & MPC & MPC & MPC & $\mathrm{a}$ & $\mathrm{a}$ & $\mathrm{a}$ \\
\hline $\mathrm{X}$ & $\begin{array}{c}-0.003 * * * \\
(0.000)\end{array}$ & $\begin{array}{c}-0.007 * * * \\
(0.001)\end{array}$ & $\begin{array}{c}-0.005 * * * \\
(0.001)\end{array}$ & $\begin{array}{c}0.053 * * * \\
(0.004)\end{array}$ & $\begin{array}{c}0.081 * * * \\
(0.022)\end{array}$ & $\begin{array}{c}0.054 * * * \\
(0.007)\end{array}$ \\
\hline$X^{2}$ & & $\begin{array}{c}0.000 * * * \\
(0.000)\end{array}$ & & & $\begin{array}{l}-0.005 \\
(0.004)\end{array}$ & \\
\hline$I^{d<1 / N}$ & & & $\begin{array}{c}-0.093 * * \\
(0.043)\end{array}$ & & & $\begin{array}{l}-0.060 \\
(0.040)\end{array}$ \\
\hline$I^{d<1 / N^{*} X}$ & & & $\begin{array}{c}0.003 * * * \\
(0.001)\end{array}$ & & & $\begin{array}{l}0.045^{*} \\
(0.025)\end{array}$ \\
\hline Constant & $\begin{array}{c}0.205 * * * \\
(0.020)\end{array}$ & $\begin{array}{c}0.294 * * * \\
(0.036)\end{array}$ & $\begin{array}{c}0.267 * * * \\
(0.026)\end{array}$ & $\begin{array}{c}-0.067 * * * \\
(0.020)\end{array}$ & $\begin{array}{c}-0.098 * * * \\
(0.027)\end{array}$ & $\begin{array}{c}-0.068 * * \\
(0.030)\end{array}$ \\
\hline Observations & 4,904 & 4,904 & 4,904 & 4,904 & 4,904 & 4,904 \\
\hline $\mathrm{AIC}$ & -1698.896 & -1733.603 & -1754.967 & -1735.184 & -1737.518 & -1741.457 \\
\hline $\mathrm{BIC}$ & -1646.914 & -1675.123 & -1689.989 & -1683.202 & -1679.038 & -1676.479 \\
\hline
\end{tabular}

Table D11 continued 


\begin{tabular}{|c|c|c|c|c|c|c|c|c|c|}
\hline & (1) & (2) & (3) & $(4)$ & $(5)$ & $(6)$ & (7) & (8) & (9) \\
\hline VARIABLES & $\mathrm{N}$ & $\mathrm{N}$ & $\mathrm{N}$ & MPCR & MPCR & MPCR & $\mathrm{d}$ & $\mathrm{d}$ & $\mathrm{d}$ \\
\hline \multirow[t]{2}{*}{$\mathrm{X}$} & $-0.001 * * *$ & 0.002 & $-0.002 * * *$ & $1.632 * * *$ & $4.010 * * *$ & $1.420 * * *$ & $2.639 * * *$ & $5.300 * * *$ & $2.427 * * *$ \\
\hline & $(0.000)$ & $(0.002)$ & $(0.000)$ & $(0.247)$ & $(0.445)$ & $(0.261)$ & $(0.245)$ & $(0.713)$ & $(0.293)$ \\
\hline \multirow[t]{2}{*}{$\mathrm{X}^{2}$} & & -0.000 & & & $-11.825 * * *$ & & & $-25.097 * * *$ & \\
\hline & & $(0.000)$ & & & (2.110) & & & (6.796) & \\
\hline \multirow[t]{2}{*}{$I^{d<1 / N}$} & & & $-0.227 * * *$ & & & $-0.050 *$ & & & -0.030 \\
\hline & & & $(0.038)$ & & & $(0.026)$ & & & $(0.019)$ \\
\hline \multirow[t]{2}{*}{$I^{d<1 / N_{*}} X$} & & & $0.002 * * *$ & & & -0.418 & & & 0.401 \\
\hline & & & $(0.001)$ & & & $(0.587)$ & & & $(0.928)$ \\
\hline \multirow[t]{2}{*}{ Constant } & $-0.253 * * *$ & $-0.329 * * *$ & $-0.124 * * *$ & $-0.392 * * *$ & $-0.476 * * *$ & $-0.355 * * *$ & $-0.387 * * *$ & $-0.430 * * *$ & $-0.371 * * *$ \\
\hline & $(0.038)$ & $(0.064)$ & $(0.041)$ & $(0.038)$ & $(0.041)$ & $(0.039)$ & $(0.037)$ & $(0.038)$ & $(0.038)$ \\
\hline Observations & 4,904 & 4,904 & 4,904 & 4,904 & 4,904 & 4,904 & 4,904 & 4,904 & 4,904 \\
\hline $\mathrm{AIC}$ & 4533.773 & 4529.783 & 4402.623 & 4418.566 & 4373.050 & 4391.561 & 4354.040 & 4338.057 & 4354.272 \\
\hline $\mathrm{BIC}$ & 4585.755 & 4588.264 & 4467.601 & 4470.548 & 4431.531 & 4456.539 & 4406.022 & 4396.537 & 4419.250 \\
\hline
\end{tabular}

Table D12: Tobit regression of individual last-round contributions 


\begin{tabular}{|c|c|c|c|c|c|c|}
\hline & $(10)$ & $(11)$ & (12) & (13) & (14) & $(15)$ \\
\hline VARIABLES & MPC & MPC & MPC & $\mathrm{a}$ & $\mathrm{a}$ & $\mathrm{a}$ \\
\hline $\mathrm{X}$ & $\begin{array}{c}-0.003 * * * \\
(0.000)\end{array}$ & $\begin{array}{c}-0.010 * * * \\
(0.002)\end{array}$ & $\begin{array}{c}-0.006 * * * \\
(0.001)\end{array}$ & $\begin{array}{c}0.062 * * * \\
(0.007)\end{array}$ & $\begin{array}{c}0.024 \\
(0.037)\end{array}$ & $\begin{array}{c}0.067 * * * \\
(0.011)\end{array}$ \\
\hline$X^{2}$ & & $\begin{array}{c}0.000 * * * \\
(0.000)\end{array}$ & & & $\begin{array}{c}0.007 \\
(0.007)\end{array}$ & \\
\hline$I^{d<1 / N}$ & & & $-0.214 * * *$ & & & 0.043 \\
\hline$I^{d<1 / N_{* X}}$ & & & $\begin{array}{c}(0.068) \\
0.005 * * * \\
(0.001)\end{array}$ & & & $\begin{array}{c}(0.062) \\
-0.018 \\
(0.038)\end{array}$ \\
\hline Constant & $\begin{array}{c}-0.162 * * * \\
(0.038)\end{array}$ & $\begin{array}{c}-0.008 \\
(0.063)\end{array}$ & $\begin{array}{c}-0.079 \\
(0.048)\end{array}$ & $\begin{array}{c}-0.470 * * * \\
(0.041)\end{array}$ & $\begin{array}{c}-0.426 * * * \\
(0.052)\end{array}$ & $\begin{array}{c}-0.490 * * * \\
(0.050)\end{array}$ \\
\hline Observations & 4,904 & 4,904 & 4,904 & 4,904 & 4,904 & 4,904 \\
\hline $\mathrm{AIC}$ & 4421.723 & 4399.233 & 4398.311 & 4391.530 & 4391.673 & 4394.471 \\
\hline $\mathrm{BIC}$ & 4473.705 & 4457.714 & 4463.289 & 4443.513 & 4450.154 & 4459.449 \\
\hline
\end{tabular}

Table D12 continued 